\title{
Evaluation of hydraulic conductivity of subsoil using electrical resistivity and ground penetrating radar data: example from Southwestern Nigeria
}

\author{
A. O. Salako* and A. A. Adepelumi
}

*Correspondence:

salakoademi@gmail.com

Department of Geology,

Obafemi Awolowo University,

Ile-Ife, Nigeria

\begin{abstract}
Groundwater seepage has being linked to the cause of building failures in Erinle area, Ede metropolis, SW Nigeria. A comparative study of the hydraulic conductivity (K) of first two subsoil or subsurface layers underlying the area of investigation was carried out using data acquired from ground penetrating radar (GPR) and electrical resistivity (ER) surveys. Ground penetrating radar (GPR) and electrical survey (ER) were performed along eight traverses over the shallow subsurface. From these a total of eight radar sections and geoelectric sections were developed along an electrode separation of $80 \mathrm{~m}$. The results from the radar section and geoelectric section show that the area under investigated is made up of three stratigraphic layers (laterite topsoil, weathered layer, bedrock). The radar sections show that the second subsurface layer (weathered layer) or subsoil is pervious as compared to the others. The weathered layer shows relatively smooth reflections suggesting high groundwater flow which accounts probably for the groundwater seepage observed. Hydraulic plots and Porosity confirms the pervious nature of the weathered layer as oppose to the other two layers as expressed by high hydraulic conductivity (K) values of $1.0 \times 10^{-5}-7.4 \times 10^{-6} \mathrm{~m} / \mathrm{s}$ and high porosity values of 2.16-5.06 which makes it liable to groundwater seepages. Both the ER and GPR surveys confirmed that the second subsurface layer (weathered layer) is more prone to groundwater seepage especially in traverses $(1,2,3$ and 5$)$ where the relative thickness of the first layer (lateritic topsoil) is less than $5 \mathrm{~m}$ and in traverses $(4,6,7$ and 8) having a resistive layer (basement). This study shows the importance of geophysical investigation in detect of groundwater seepage and post-foundation investigations.
\end{abstract}

Keywords: Radar, Resistivity, Seepages, Hydraulic conductivity, Porosity

\section{Background}

Groundwater seepages, is one of the basic problems associated with tropical environments especially in seasons of heavy rainfalls. Groundwater seepages are often found to be in close association with geological and tectonic factors for example, faults, fractures and cavities within the subsurface [6,9]. The mechanical strength of any subsurface layer or subsoil is connected to its soil type, hydraulic conductivity (K), resistivity and porosity. These are basic properties considered by engineers when constructing roads

(C) 2016 Salako and Adepelumi. This article is distributed under the terms of the Creative Commons Attribution 4.0 International License (http://creativecommons.org/licenses/by/4.0/), which permits unrestricted use, distribution, and reproduction in any medium, provided you give appropriate credit to the original author(s) and the source, provide a link to the Creative Commons license, and indicate if changes were made. 
or building foundations [8]. These properties (hydraulic conductivity, porosity, permeability and water content distribution etc.) which could be extracted from the radar sections and hydraulic plots are important in the occurrence of groundwater seepage and the prediction of sustainable foundation in the study area.

The hydraulic conductivity (K) of subsoil is a primary factor considered in the analytical design of civil engineering structures and the tackling of environmental related issues like groundwater seepages, drainages, landfills and efficient sewage disposal units. The variation in hydraulic conductivities of subsoil is a function of its intrinsic permeability, degree of saturation, viscosity of fluid moving through the subsoil, the structure and lithology of the geological formation [28].

Several authors have posited varying approaches in the determination of hydraulic conductivity of saturated and unsaturated soils in the tropics and temperate regions of the world using varying techniques. Unlike other approaches adopted in the determination of hydraulic conductivity; the adoption of a geophysical technique (use of GPR and Electrical Resistivity surveys) provide low cost and faster technique for acquiring vast information on the physical properties of the soils [10, 27]. The use of geophysical techniques in the determination of hydraulic conductivity stems from the works of Matsui et al. [12] and Antonio Costa [3]. Matsui et al. [12] showed that a direct relationship exist(s) between resistivity and hydraulic conductivity in granitic rocks while [3] showed a permeability-porosity relationship between pores spaces and fractures found within the subsoil. The relationship showed that though the subsoil might be porous, they might not necessarily be permeable (clay) except in cases where pores spaces within the subsoil are interconnected (weathered material).

The objective of this study is to investigate ground seepage occurrence through the evaluation of the hydraulic conductivity of subsoil (lateritic topsoil, weathered layer) and the basement viz a viz the integrity of foundations in the study area.

\section{Site description}

\section{Study location}

The study was carried lies within the Adeje Estate that lies within Erinle area of the Ede metropolis, Osun State, Nigeria (Figs. 1,2) which is bounded in the north by Kwara State, in the east partly by Ekiti State and Ondo State. It is situated between latitudes $7^{\circ} 45^{\prime} 1^{\prime \prime} \mathrm{N}$ and $7^{\circ} 45^{\prime} 3^{\prime \prime} \mathrm{N}$, and longitudes $4^{\circ} 25^{\prime} 49^{\prime \prime} \mathrm{E}$ and $4^{\circ} 25^{\prime} 52^{\prime \prime} \mathrm{N}$ (Fig. 2) and its mostly accessible through footpaths and the Ede-Oshogbo Road (Fig. 1).

\section{Geology of study area}

The local geology of the study area is underlain by rocks of the Migmatite-Gneiss Quartzite complex which falls within the Precambrian Basement Complex of SW Nigeria (Fig. 3) that forms one of the six lithologic groups making up the Nigeria basement complex as described extensively by Oyawoye [20], Rahaman [21, 22], Odeyemi [15] and MuCurry [14]. According to Rahaman [22], the Nigeria basement consists of six groups namely; (1) the migmatite-gneiss-quartzite complex (2) the meta-sedimentary and meta-igneous rocks (3) charnokitic, gabbroic and dioritic rocks (4) older granites (5) calc-alkaline volcanics and hypabyssal rocks (6) the basic and syenite dykes. The study area when considered more closely is made up three lithological units namely; (1) the 


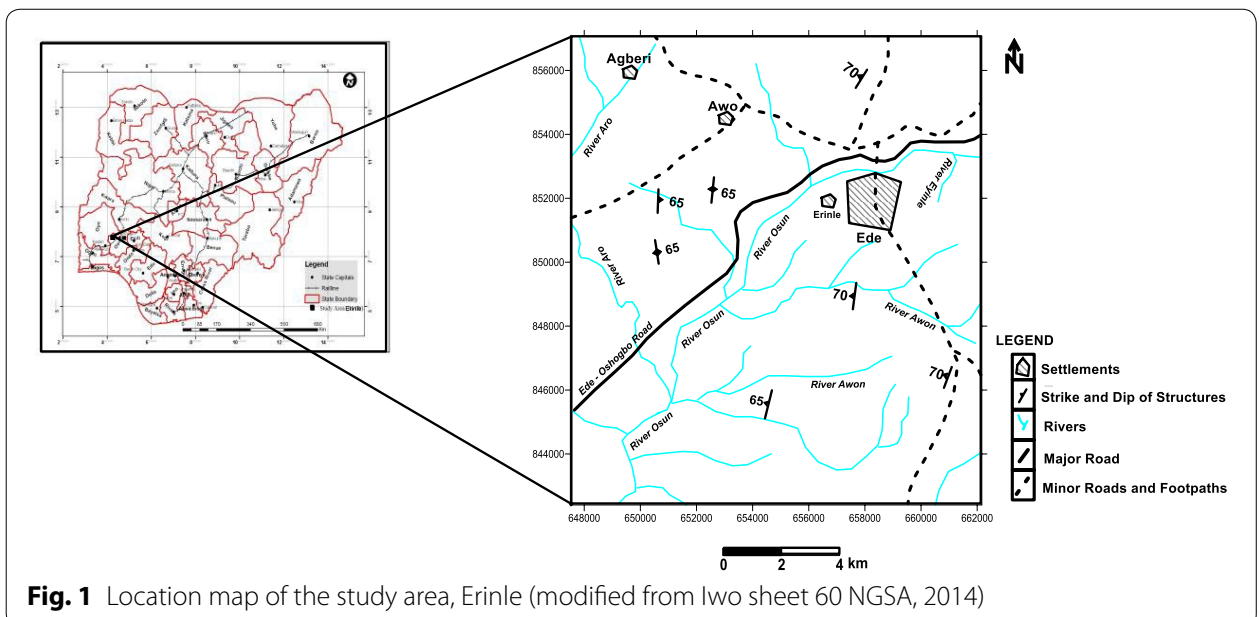

Fig. 1 Location map of the study area, Erinle (modified from Iwo sheet 60 NGSA, 2014)

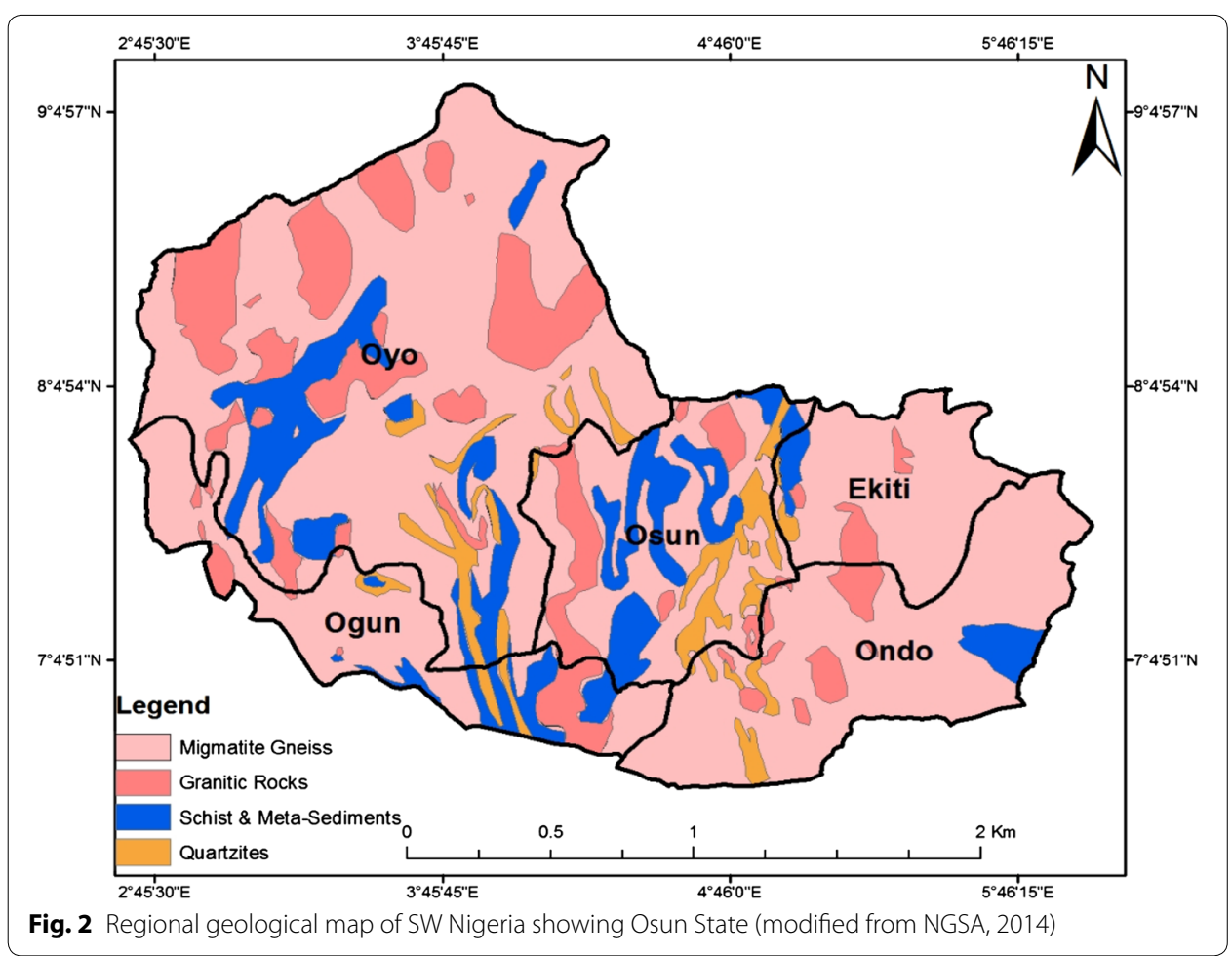

undifferentiated migamatite (2) the charnokites meta-intrusives and lastly (3) the pegmatites which are briefly discussed below: (1) The undifferentiated migmatite occurs at the northwestern region of the study area as shown (Fig. 3). The colour of the rock is gray and its texture ranges from medium-coarse. Its mineralogical composition comprises of quartz, plagioclase, orthoclase feldspar and biotite (2) the charnokites meta-instrusives rocks in the study area occur along the margins within the gneiss and migmatite (undifferentiated). The charnockitic meta-intrusive are composed of quartz, alkali feldspars, plagioclase, orthopyroxene, clinopyroxene, hornblende, biotite and accessory amounts of opaque ore apatite and zircon [17] (3) The pegmatites are the youngest set of rock 


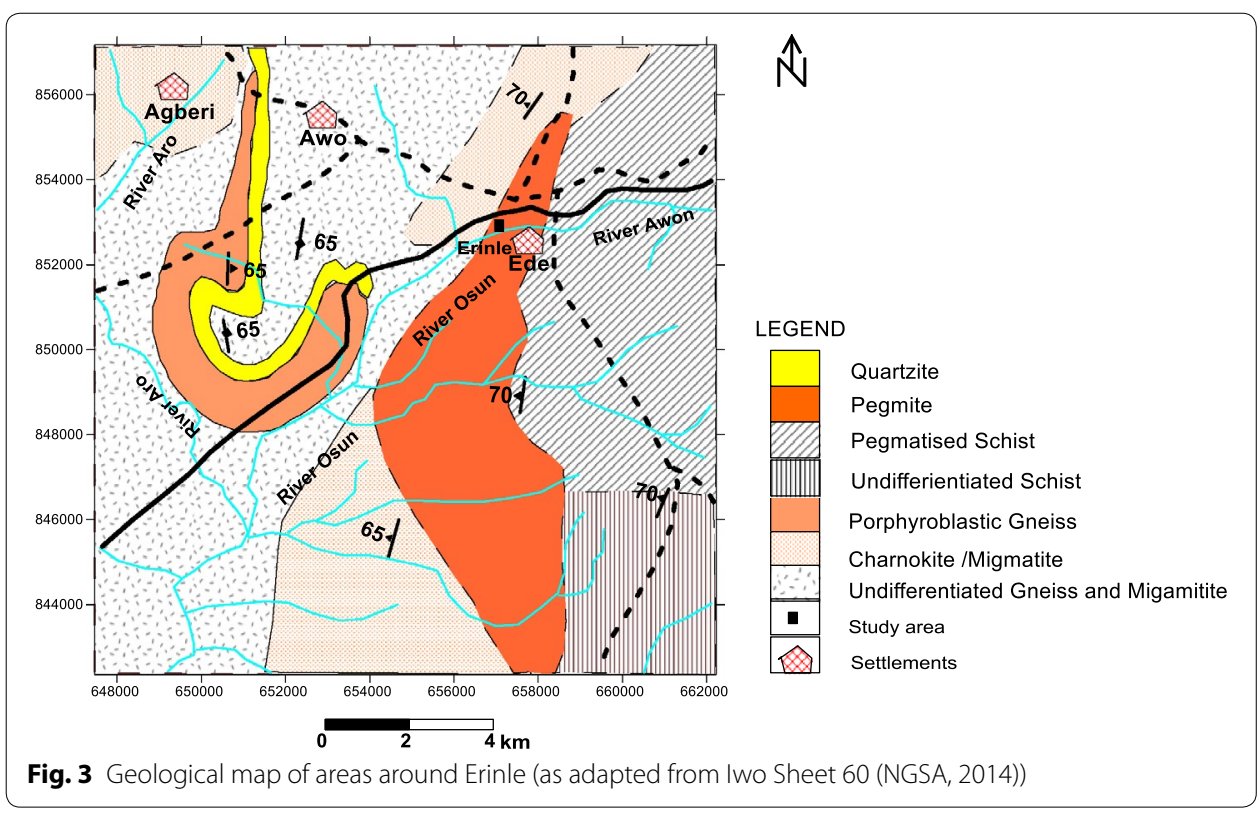

types found in the study area. It is found to be composed mainly of microcline and quartz which is widespread throughout the study area. It is frequently found associated with the gneisses and older granites. Pegmatite in older granite rock is a regular tabular body with a fairly constant strike and dip [21].

\section{Structural geology of study area}

A study of the structural geology of the study area was essential as the study of geological structures provide clues to how groundwater seepages could weaken the foundation of buildings. Previous works show that rocks within the area under investigation has been subjected to some form of deformational episodes characterized by geological structures such as fractures, faults $[2,18,19]$ and events of plasticity. The presence of these structures coupled with individual subsurface properties (porosity and permeability) has led to either an increase or a decrease in the occurrence of groundwater seepages viz a viz its negative effect on stability of buildings within the study area.

\section{Methods}

The geophysical data used for this research were acquired using two different geophysical methods namely; the ground penetrating radar (GPR) and the electrical resistivity (ER) method. Eight traverses where established for the GPR and ER surveys. Seven of the eight traverses established for the survey runs west-east while the remain one ran north-south of the general strike of the geology of the study area with lengths of between $80-100 \mathrm{~m}$. The survey design used in the study is presented in Fig. 4.

\section{Ground penetrating radar (GPR)}

The GPR is efficient in mapping out shallow targets (fractures or voids within subsoil etc.). This is carried out by the use of high-frequency electromagnetic pulses (usually $10-1000 \mathrm{MHz}$ ) which are generated and transferred into the ground. This way, dielectric 


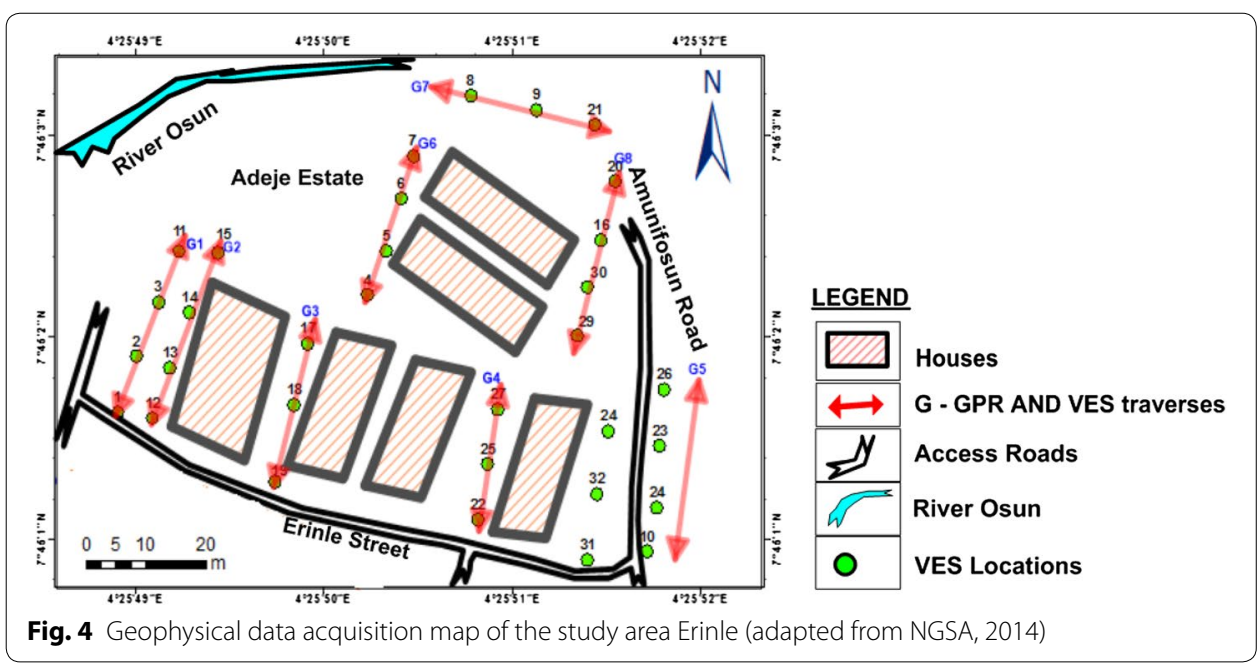

discontinuities existing between subsoil are detectable electromagnetic pulse travels through it. It is the contrast in the dielectric permittivity between the subsoil that causes reflections: the greater the difference in dielectric permittivity (variation in textural, lithology and porosity of subsoil), the greater the coefficient of reflectivity [7] which translates GPR reflection pattern variations. Best results for GPR surveys are obtainable when topographic cover is smooth and when material penetrated is dry [23].

The study was carried out using the GSSI SIR-2000 System along eight traverses each about 80-100 m long with station-station separation of $10 \mathrm{~m}$. The GPR System was coupled with a $200 \mathrm{MHz}$ shielded mono-static antenna oriented in a broadside survey direction for the investigation and characterization of the shallow subsurface. The following parameters were then adopted for use in the processing of the subsurface data acquired; Data collection mode: continuous; range: 300 ns; samples per scan: 1024. From this survey, eight radargrams were generated and subjected to processes of dewowing, filtering by distance, AGC (automatic gain control) and NMO (normal moveout).

\section{Electrical resistivity (ER)}

The use of the ER method for geophysical exploration seems to be the most applied for geophysical technique in shallow subsurface investigation. This is applied through the use of the vertical electrical sounding (VES) technique which measures vertical changes of electrical resistivity. In terms of field logistic it's economical, easy and straight forward to use.

Data acquisition for the study was carried out along the eight traverses established during the GPR survey. The Schlumberger configuration was adopted during the electrical resistivity survey with a half-current electrode spacing $(\mathrm{AB} / 2)$ varying from 1 to $80 \mathrm{~m}$. A total of 32 VES points along eight (8) traverses were occupied. The resistivity data obtained at the various stations were plotted against the half-current electrode spacing $(\mathrm{AB} / 2)$ and processed using the WinRESIST software [26]. Processed results were stacked together to develop $2 \mathrm{D}$ geoelectric section of the subsurface to better characterize the subsurface. 
To evaluate the relationship between resistivity and hydraulic conductivity of subsoil, hydraulic conductivity vs. resistivity plots were developed along traverses $1,2,3,4,5$, 6, 7 and 8 respectively. The empirical formula adopted to evaluate this relationship was established by Ogata et al. [16] and Sudo et al. [24] for estimating the hydraulic conductivity $(\mathrm{K})$ of clayey sand/clay and lateritic clay given as:

$$
\mathrm{K}=\left(3.545 \times 10^{-11}\right) \times \rho^{3.9072}
$$

where $\mathrm{K}=$ hydraulic conductivity $(\mathrm{m} / \mathrm{s})$ and $\rho=$ apparent resistivity $(\Omega \mathrm{m})$. Porosity is another property of the subsoil that could affect the occurrence of groundwater seepage viz a viz its effects on the foundational stability of buildings. To determine the porosity of the subsurface, the resistivity - porosity relation developed by Archie $[4,5]$ was used:

$$
\rho=a \times \rho w \times \varphi^{-m}
$$

where $\rho=$ Resistivity values of the subsoil $(\Omega \mathrm{m}), \mathrm{a}=$ tortuosity constant of subsoil (0.62), $\mathrm{m}=$ cementation factor constant of subsoil (2.15), $\rho \mathrm{w}=$ Resistivity of water (1000 $\Omega \mathrm{m}), \varphi=$ Porosity of subsoil. The porosity values obtained from (2) were related with the hydraulic conductivity values (1) to understand how porosity combined with hydraulic conductivity of the subsoil affects the groundwater seepage.

\section{Results and discussions}

\section{GPR sections along the traverses}

For the area of study under investigation, three subsurface layers were delineated with varying lithology and thickness based on variation in GPR reflection patterns coupled with its local geology (Fig. 3). These variations could be due to water content variation bringing about influential changes in the dielectric properties of subsurface materials (Moller, [13]). The Radargrams produced along the eight traverses (traverses 1, 2, 3, 4, 5, 6, 7 and 8) are presented and analyzed (Figs. 5, 6, 7, 8) showing three subsurface layers namely; the lateritic topsoil, weathered layer (subsoil) and lastly the basement.

The lateritic topsoil exhibits nearly planar reflection with a thickness range of about 1.2-7.2 m. The weathered layer exhibits nearly smooth to smooth reflection patterns with a thickness range of about 7.0-17.4 m. This layer consists of weathered materials (clayey-sand, sand) from the bedrock reflected as nearly smooth reflections which are probable indications of the layer been water-filled. This layer is found to be characterized by plasticity events which are found to be most pronounced in traverses 1, 2, 3 and 5 (Figs. 5, 6) and less pronounced in traverses 4, 6, 7 and 8 (Figs. 7, 8). The effects of plasticity are been reflected by wall cracks, and groundwater (Fig. 9). The basement with an infinite thickness exhibits chaotic reflections with macro diffractions; this probably due to the compact nature of the basement bedrock.

\section{Geoelectric sections along the traverses}

The purpose of developing the geoelectric sections is to understand the geological sequence of the subsoil in terms of resistivity variations and range of thickness. The resistivity variations obtained were correlated with resistivity of common geologic materials (Fig. 14). Based on these, eight geoelectric sections were developed along eight 


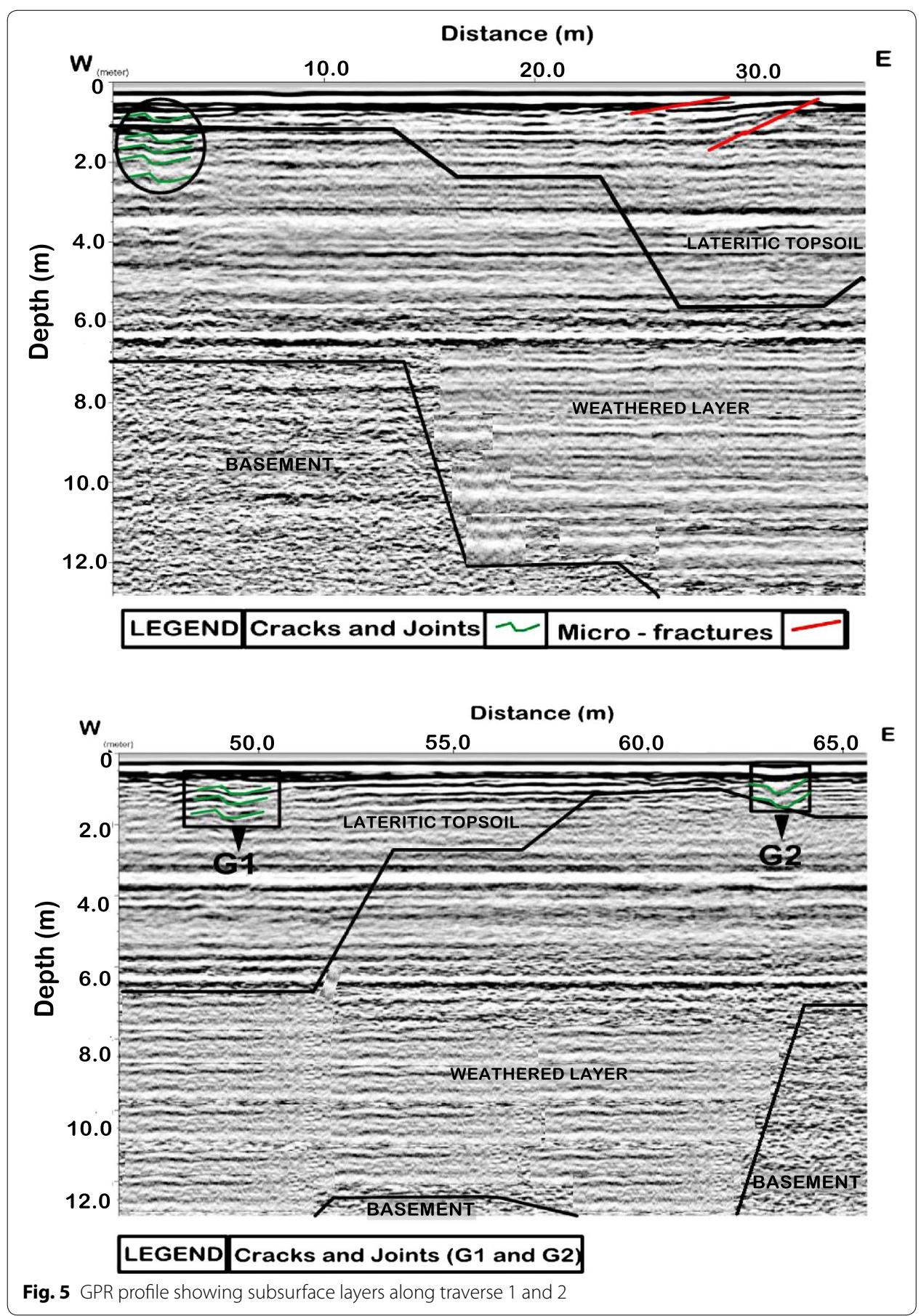

traverses (traverses 1, 2, 3, 4, 5, 6, 7 and 8) and presented (Figs. 10, 11, 12, 13) delineating three subsurface layers (the lateritic topsoil, the weathered layer and the basement bedrock) in the study area.

The lateritic topsoil has resistivity values ranging from 69 to $426 \Omega \mathrm{m}$ with a thickness layer range of $1.2-7.2 \mathrm{~m}$. The lateritic topsoil is fairly compacted with moderate resistivity values. The weathered layer had resistivity range of $19-281 \Omega \mathrm{m}$ with a thickness range of 7.0-17.4 $\mathrm{m}$ with infinity thickness on some VES data stations. The bedrock 


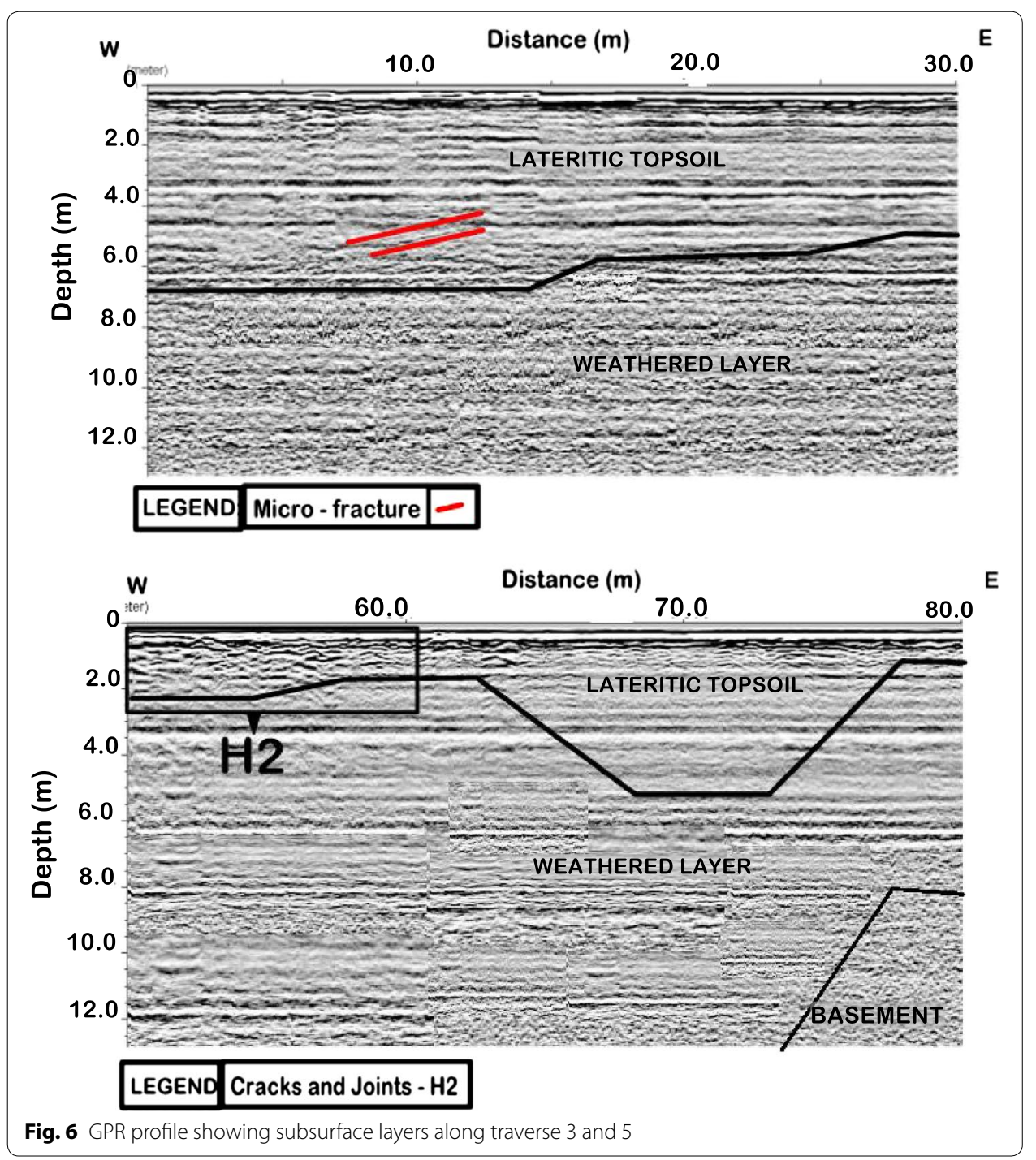

had resistivity range of $459-5289 \Omega \mathrm{m}$ and thickness range of $4.9-8.6 \mathrm{~m}$ and an infinite thickness.

The weathered layer as compared to the other two subsurface layers or geological units exhibits the lowest range resistivity values (19-281 $\Omega \mathrm{m})$. This low resistivity values could be attributed to loosely bonded sediments and probably conductive fluids and clay minerals (with anomalously low resistivity values of less than $65 \Omega \mathrm{m}$ ). Clay minerals exhibit a plasticity nature which allows it to swell when wet and contract when dry. A continuous motion of this within the weathered layer leads to the development of cracks and differential settlement. The presence of cracks and other inclined features (probably fractures) serve as conduit for water movement to the surface resulting to events of 


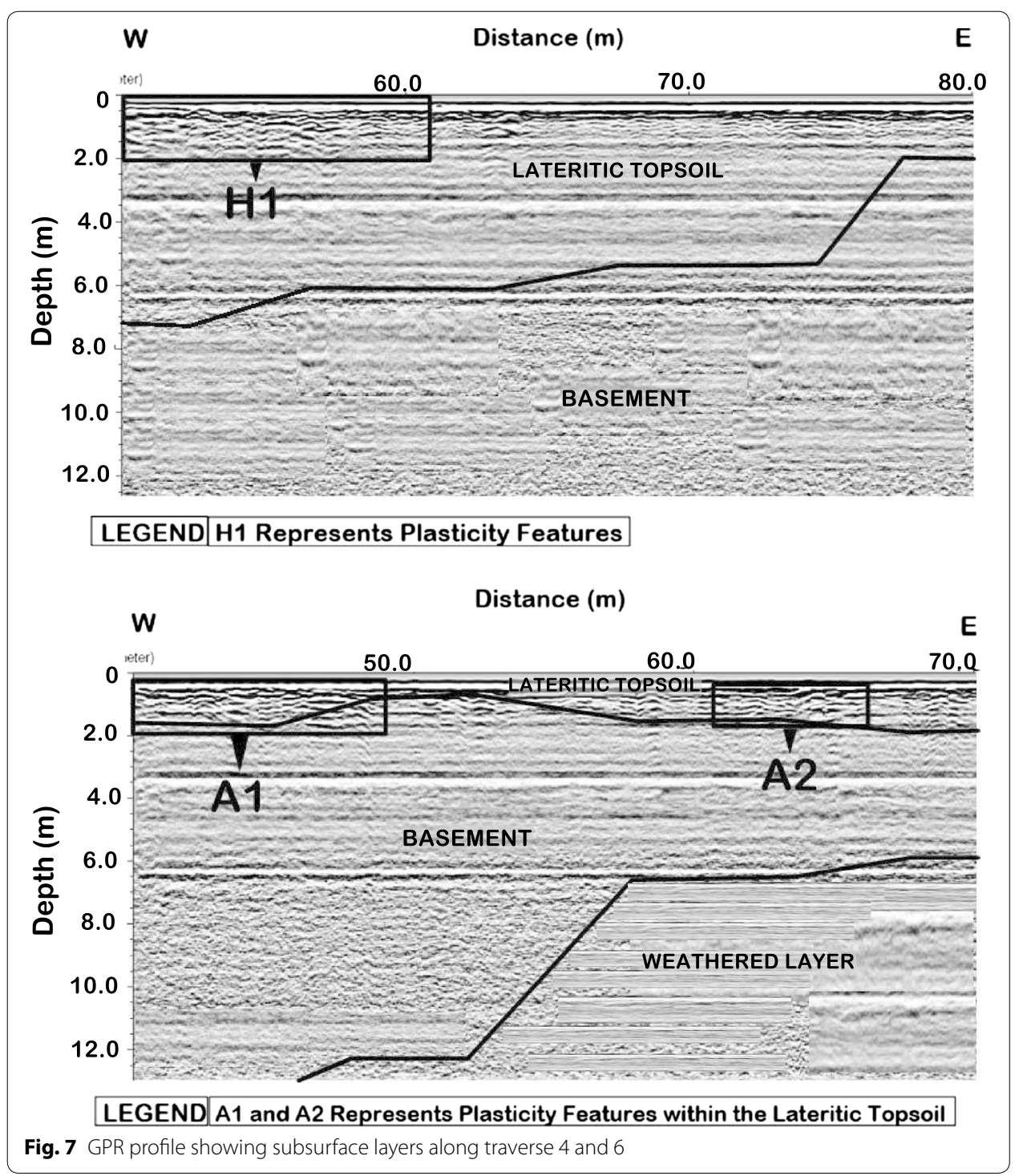

groundwater seepages in the weathered layer. This is seen to be most prominent among traverses in Figs. 10 and 11 with thicker columns of the weathered layer and anomalously low resistivity values $(<65 \Omega \mathrm{m})$ as compared to traverses in Figs. 12 and 13 with high resistivity values $(>300 \Omega \mathrm{m})$.

Depression zones observed in traverses 1 (between VES 3 and 25) and 5 (between VES 15 and 13) contains probably conductive fluid and elements of sandy clay minerals evident by their anomalously low resistivity values $(<65 \Omega \mathrm{m})$. The basement depression 


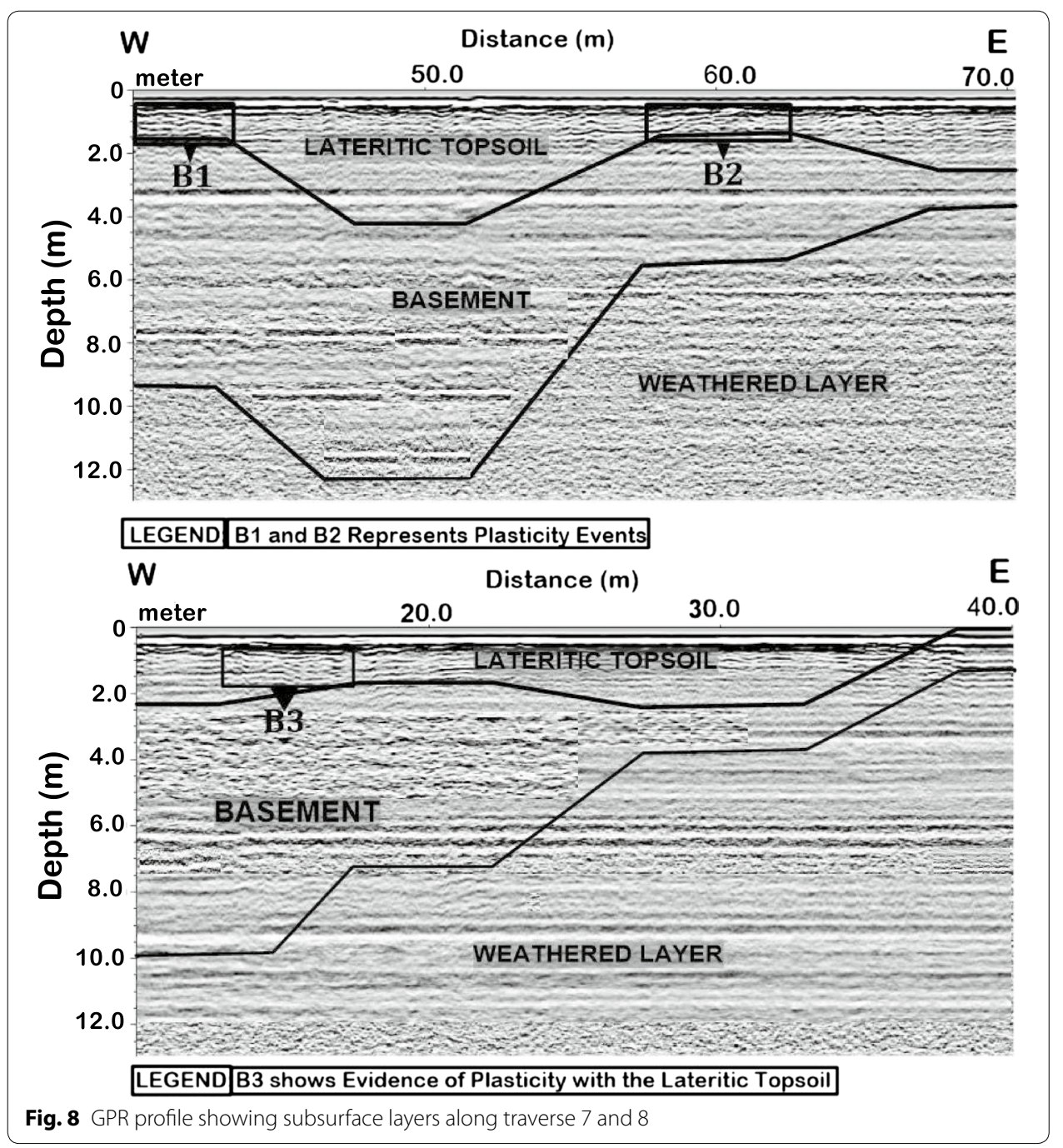

delineated in Figs. 6 and 7 possibly correspond to a fracture zone in the area. Forward modeling results generated by Adepelumi et al. [1] indicates that such basement depressions probably represent fractured bedrocks which could serve as groundwater accumulation centres. 


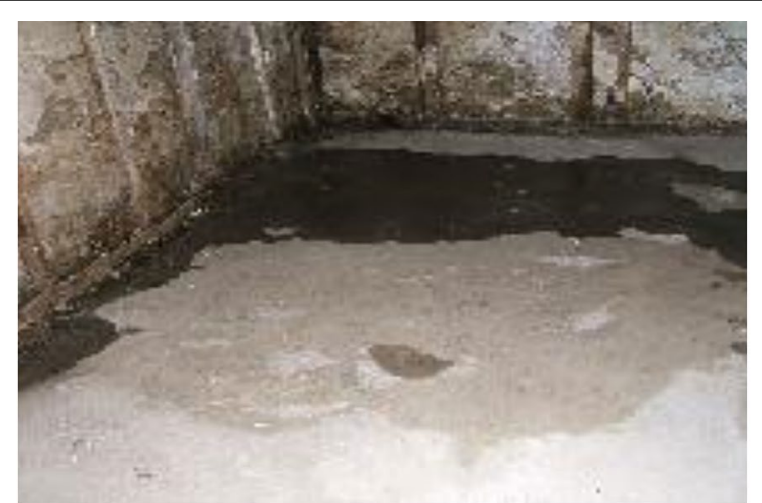

Picture Showing Groundwater Seepage through Building Floor

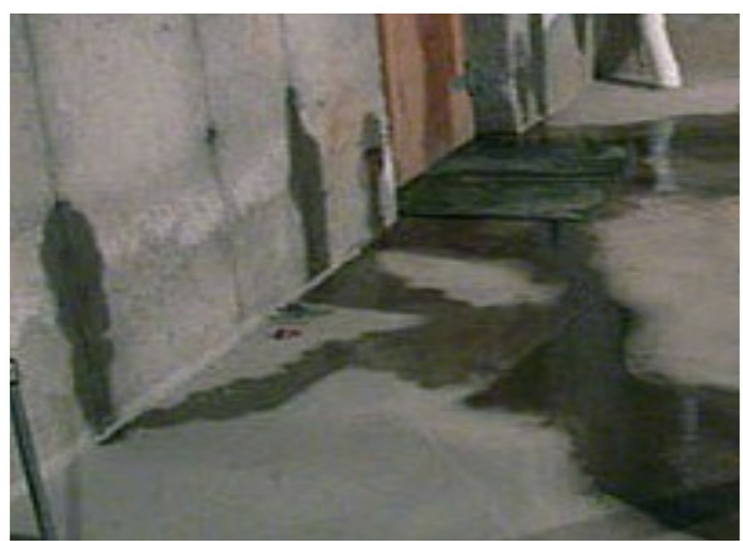

Picture Showing Groundwater Seepage through Cracks on Walls

Fig. 9 Pictures showing groundwater seepage through building

\section{Hydraulic conductivity, resistivity and porosity of subsoil}

Lima and Niwas [11] suggested that hydraulic conductivity is dependent on the type of formation (subsoil type) and its fluid properties. However when the same fluid type flows through the subsoil, the rate of the hydraulic conductivity is found to be dependent on the subsoil make-up. For this research the weathered layer is considered probably constituting materials like loosed sediments and sandy-clay materials (based on resistivity variation as typified by the resistivity table in Fig. 15 correlated with resistivity values obtain for this survey). This variation in resistivity values observed within the weathered layer and the basement influences their hydraulic conductivity values (Eq. 1) as observed by the hydraulic conductivity and resistivity plots.

Hydraulic conductivity vs. resistivity plots (Figs. 15, 16, 17, 18) were developed from the inversion of resistivity and derived hydraulic conductivity values from Eq. 1. The purpose of this plots is to show how hydraulic conductivity and resistivity are related 


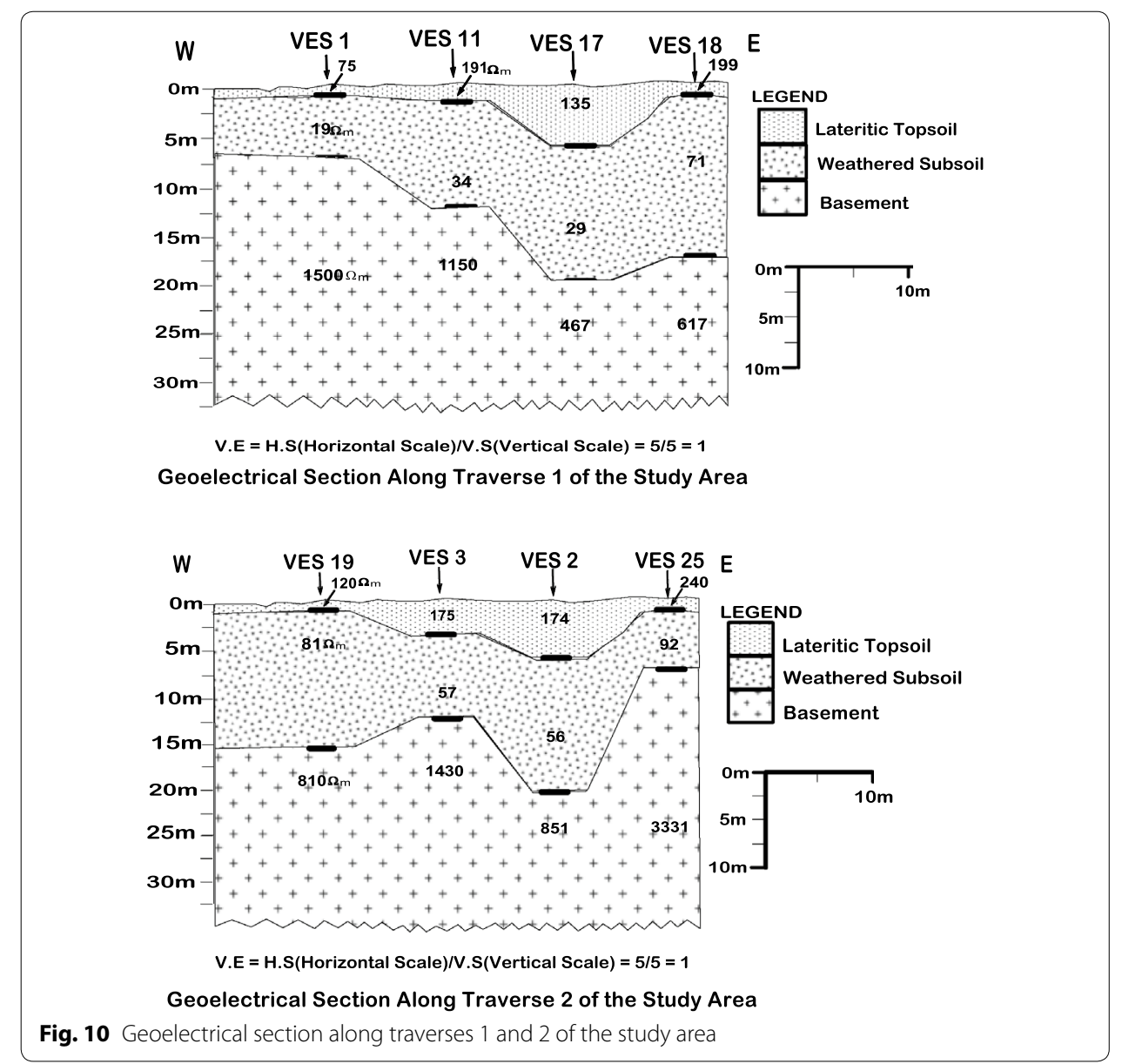

viz a viz their influence on groundwater seepage experienced in the study area. The hydraulic conductivity vs. resistivity plots show direct relationship exists between the hydraulic conductivity and resistivity (for the weathered layer) viz a viz the occurrence of groundwater seepage. This was done while considering the first 6-8 $\mathrm{m}$ depth of the subsoil (probably depth at which most foundations are laid). A decrease or increase in hydraulic conductivity values of subsurface layer (subsoil) is a function of the hydraulic properties (porosity, permeability) of the subsurface layers. Two different scenarios where considered; the first is a porous and permeable subsurface layer (weathered 


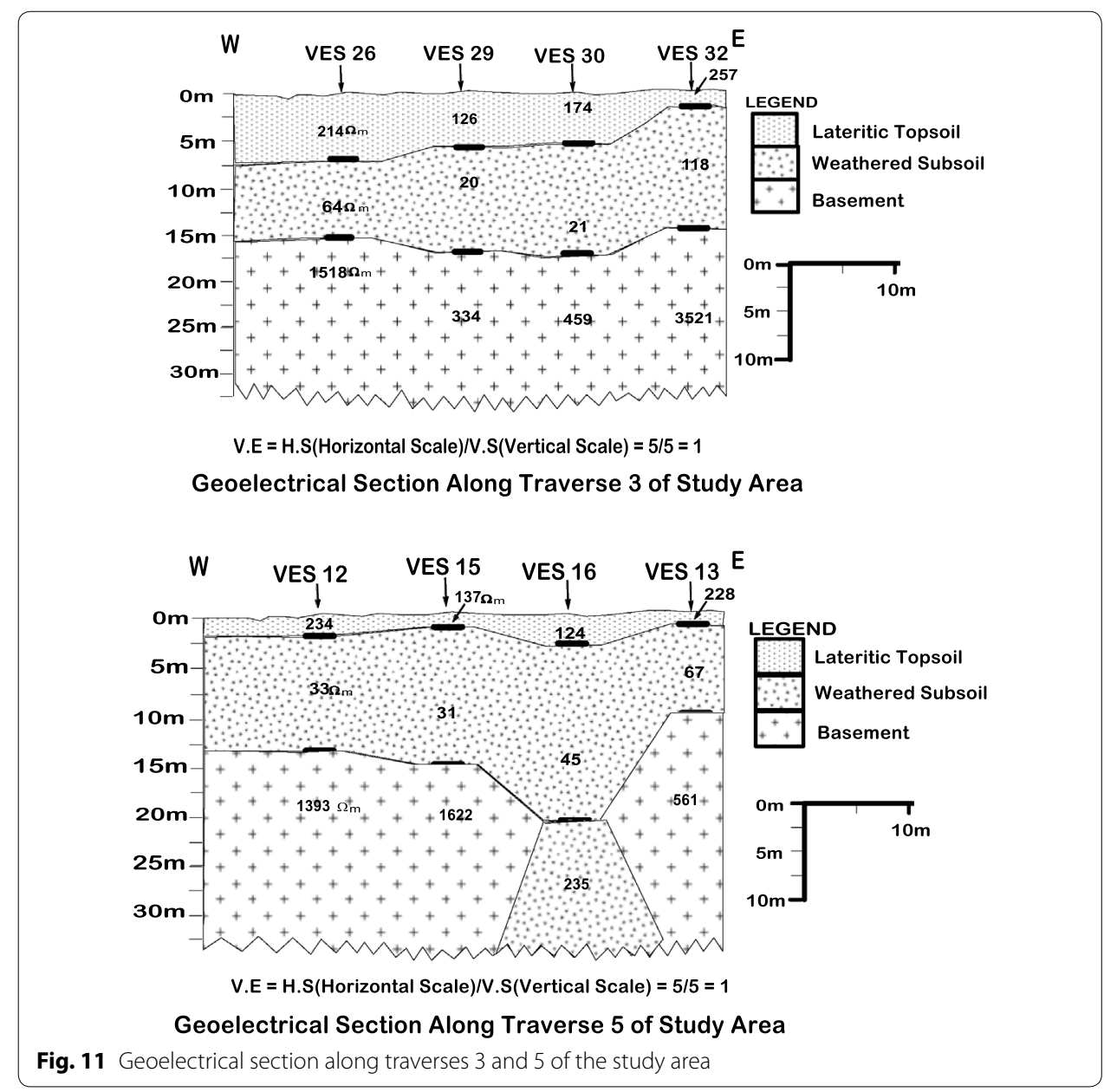

layer) while the second is a less porous/permeable (lateritic topsoil and basement). For these two scenarios, a linear relationship is observed between resistivity and hydraulic conductivity (K). For the porous/permeable subsurface layer (weathered layer), high hydraulic conductivity values is observed with a corresponding low resistivity. However for the porous/low permeable subsurface layer (lateritic topsoil) and basement (non-porous/impermeable subsurface layer), low hydraulic conductivities is observed (Figs. 16, 17) with corresponding high resistivities. The high hydraulic conductivity values $\left(2.0 \times 10^{-5}-6.7 \times 10^{-6} \mathrm{~m} / \mathrm{s}\right)$ in the weathered layer probably suggest its liability to groundwater seepages through cracks and micro-fractures found within it. This seems 


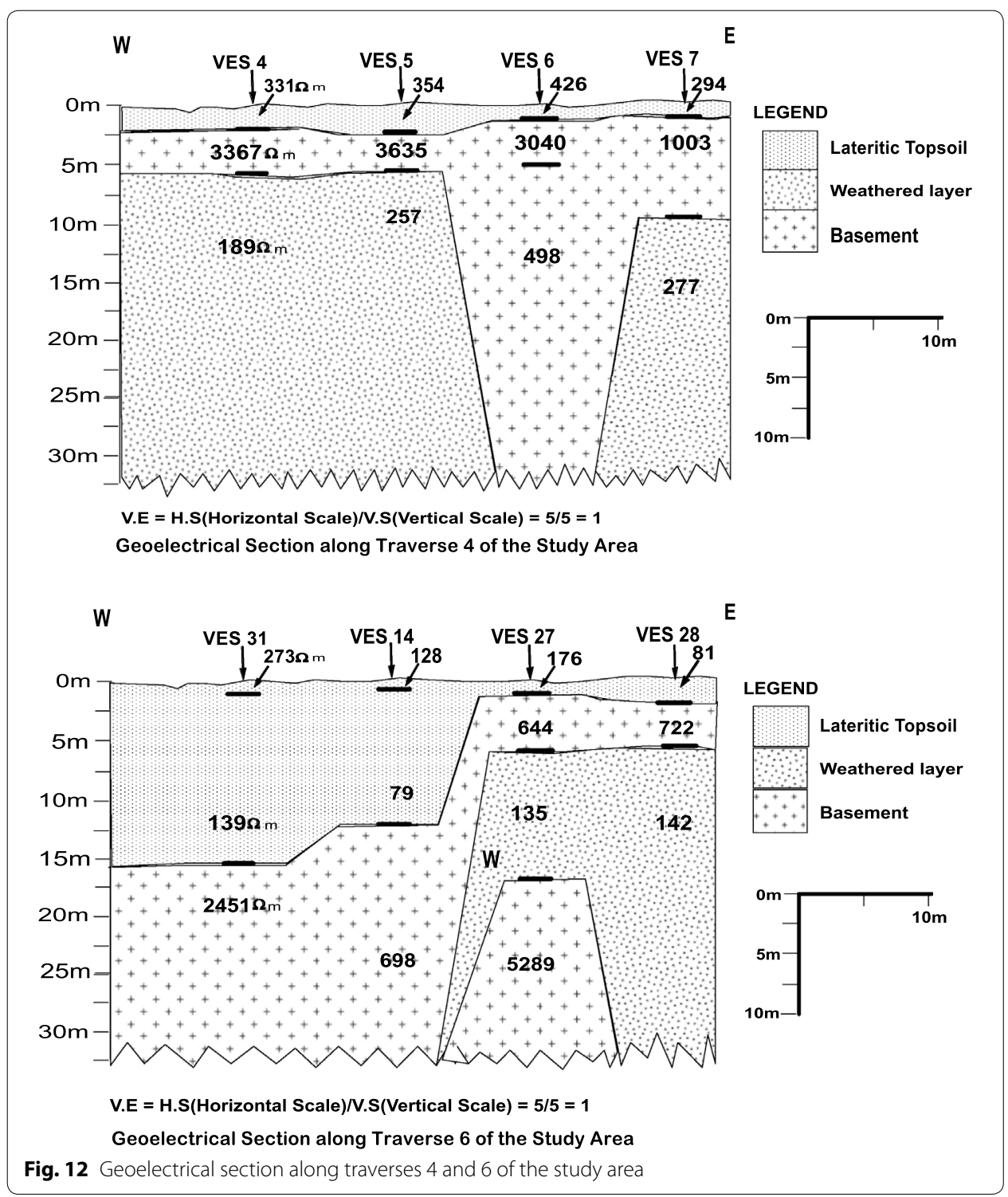

to be the case among houses located along traverses 1, 2, 3 and 5 (Figs. 6, 7). The low hydraulic conductivity values in the lateritic topsoil $\left(2.4 \times 10^{-5}-9.0 \times 10^{-5} \mathrm{~m} / \mathrm{s}\right)$ and the basement $\left(1.1 \times 10^{-4}-4.5 \times 10^{-5} \mathrm{~m} / \mathrm{s}\right)$ with corresponding high resistivity values suggest that it's less liable to groundwater seepages (Figs. 7, 8). The higher hydraulic conductivity values observed for the lateritic topsoil as compared to the lower hydraulic conductivity observed for the basement is probably due to the porous yet less permeable nature of clay minerals that make up the lateritic topsoil. This is observed along traverses 6 (VES 31 and 14), traverse 7 (VES 20) and 8 (VES 21) at depths of about $5 \mathrm{~m}$ which coincides with depth at which building foundations are laid. 


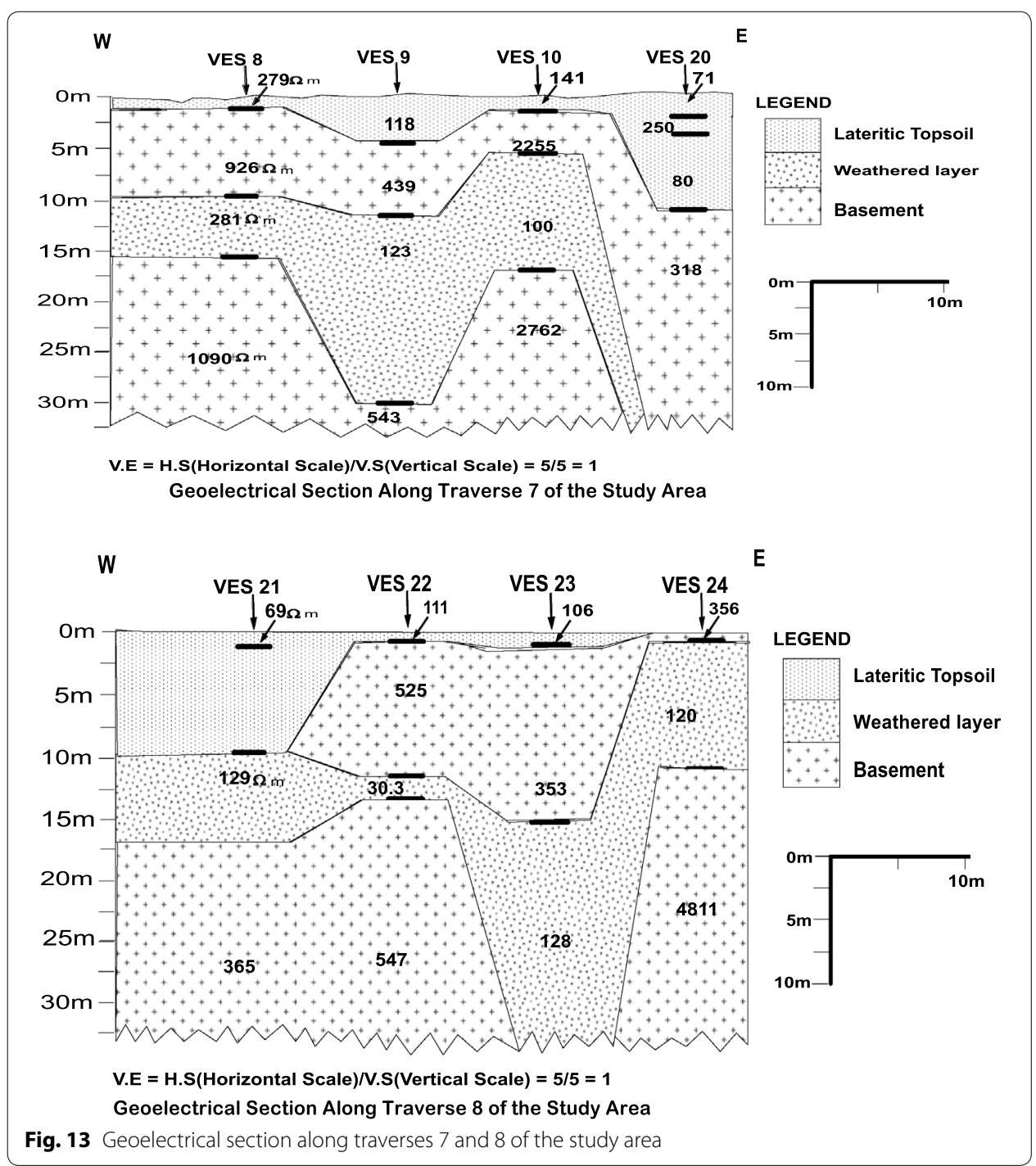

The resistivity vs. porosity plots (Figs. 19, 20, 21, 22) shows how resistivity varies with porosity along the eight different traverses being investigated viz a viz its relation to the occurrence of groundwater seepages. The calculated values of porosity of subsurface layers from the resistivity equation (Eq. 2) is done to with a view of stating the relationship between porosity, resistivity and in extension hydraulic conductivity (effective permeability) viz a viz its influence on groundwater seepages. The lithological build of subsurface layers influences to a great extent its effective permeability (hydraulic conductivity) 


\begin{tabular}{|c|c|}
\hline Material & Nominal resistivity $(\Omega \mathrm{m})$ \\
\hline $\begin{array}{l}\text { Sulphides: } \\
\text { Chalcopyrite } \\
\text { Pyrite } \\
\text { Pyrrhotite } \\
\text { Galena } \\
\text { Sphalerite }\end{array}$ & $\begin{array}{l}1.2 \times 10^{-5}-3 \times 10^{-1} \\
2.9 \times 10^{-5}-1.5 \\
7.5 \times 10^{-6}-5 \times 10^{-2} \\
3 \times 10^{-5}-3 \times 10^{2} \\
1.5 \times 10^{7}\end{array}$ \\
\hline $\begin{array}{l}\text { Oxides: } \\
\text { Hematite } \\
\text { Limonite } \\
\text { Magnetite } \\
\text { Ilmenite }\end{array}$ & $\begin{array}{l}3.5 \times 10^{-3}-10^{7} \\
10^{3}-10^{7}-5-5.7 \times 10^{3} \\
5 \times 10^{-5}-5.70^{-3}-5 \times 10 \\
10^{-3}\end{array}$ \\
\hline $\begin{array}{l}\text { Quartz } \\
\text { Rock salt } \\
\text { Anthracite } \\
\text { Lignite }\end{array}$ & $\begin{array}{l}3 \times 10^{2}-10^{6} \\
3 \times 10-10^{13} \\
10^{-3}-2 \times 10^{5} \\
9-2 \times 10^{2}\end{array}$ \\
\hline $\begin{array}{l}\text { Granite } \\
\text { Granite (weathered) } \\
\text { Syenite } \\
\text { Diorite } \\
\text { Gabbro } \\
\text { Basalt } \\
\text { Schists (calcareous and mica) } \\
\text { Schist (graphite) } \\
\text { Slates } \\
\text { Marble } \\
\text { Consolidated shales } \\
\text { Conglomerates } \\
\text { Sandstons } \\
\text { Limestones } \\
\text { Dolomite } \\
\text { Marls } \\
\text { Clays } \\
\text { Alluvium and sand } \\
\text { Moraine }\end{array}$ & $\begin{array}{l}3 \times 10^{2}-\times 10^{6} \\
3 \times 10-5 \times 10^{2} \\
10^{2}-10^{6} \times 10^{6} \\
10^{4}-10^{5} \\
10^{3}-10^{6} \\
10-1.3 \times 10^{7} \\
20-10^{4} \\
10-10^{2} \\
6 \times 10^{2}-4 \times 10^{7} \\
10^{2}-2.5 \times 10^{8} \\
20-2 \times 10^{3} \\
2 \times 10^{3}-10^{4} \\
1-7.4 \times 10^{8} \\
5 \times 10-10^{7} \\
3.5 \times 10^{2}-5 \times 10^{3} \\
3-7 \times 10^{3} \\
1-70^{2} \\
10-8 \times 10^{2} \\
10-5 \times 10^{3}\end{array}$ \\
\hline 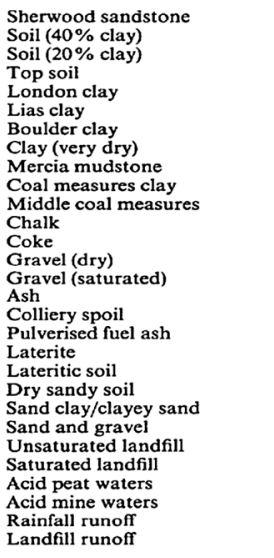 & $\begin{array}{l}100-400 \\
8 \\
33 \\
250-1700 \\
4-20 \\
10-15 \\
15-35 \\
550-150 \\
20-60 \\
50 \\
>100 \\
50-150 \\
0.2-8 \\
1400 \\
100 \\
40-20 \\
10-20 \\
50-100 \\
800-1500 \\
120-750 \\
80-1050 \\
30-215 \\
30-225 \\
30-100 \\
15-30 \\
100 \\
20 \\
20-100 \\
<10-50\end{array}$ \\
\hline $\begin{array}{l}\text { Glacier ice (temperate) } \\
\text { Glacier ice (polar) } \\
\text { Pcrmafrost }\end{array}$ & $\begin{array}{l}2 \times 10^{6}-1.2 \times 10^{8} \\
5 \times 10^{4}-3 \times 10^{3 *} \\
10^{3}->10^{4} \\
\end{array}$ \\
\hline
\end{tabular}

Fig. 14 Resistivity of common geologic materials (adopted from [25])

thus lateritic topsoil made up of mainly clay minerals that are highly porous would have moderate resistivity and low permeability. This however is not case with basement, as it has much more higher resistivity with corresponding low porousity and permeability as compared to the lateritic topsoil. 


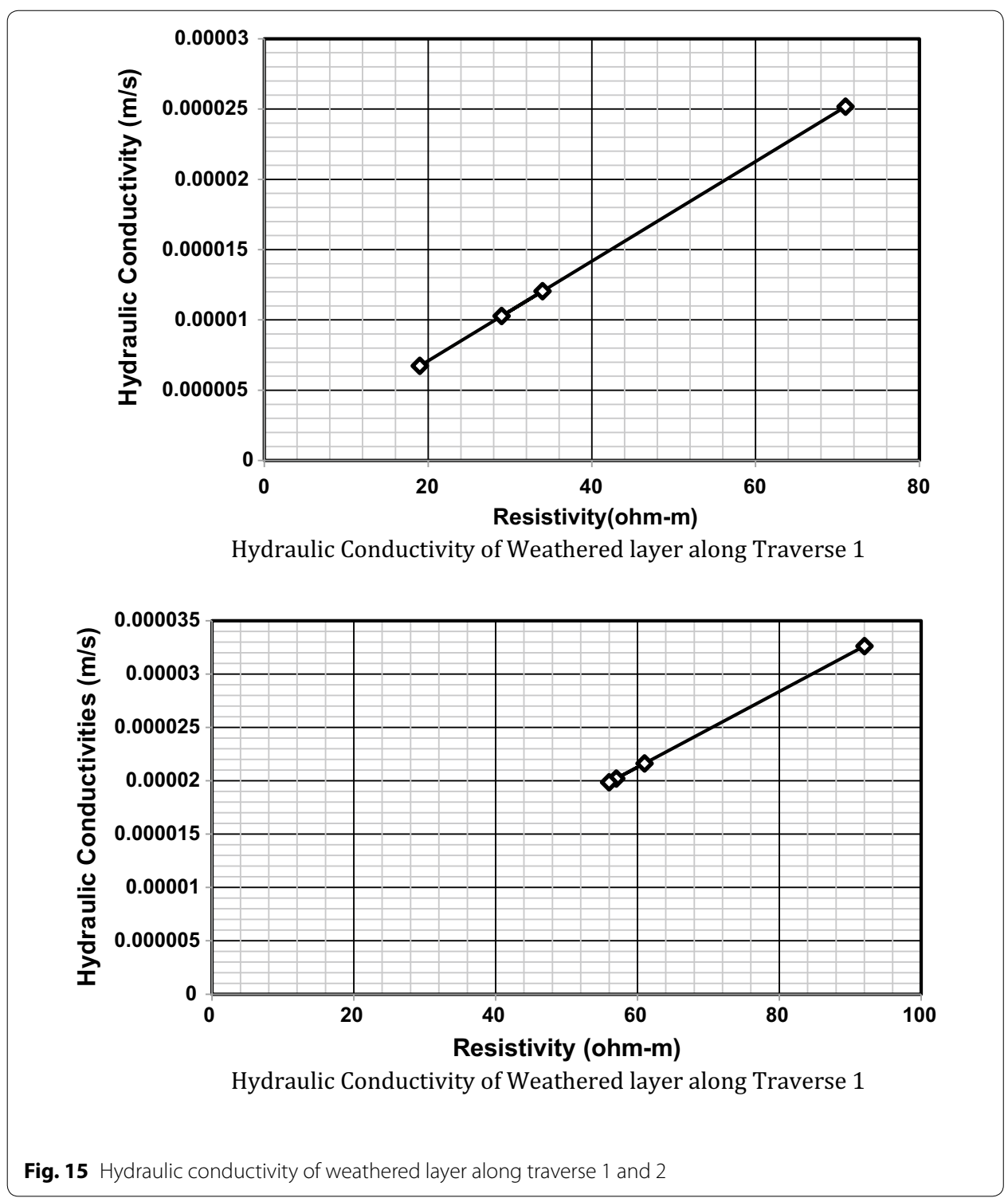

\section{Correlation of results}

Results obtained from the GPR survey and electrical resistivity (ER) Survey is presented in form of radargrams and geoelectrical sections respectively with the aim of correlation. That is to know how much similar results obtained from the two different surveys are in terms of evaluating the hydraulic conductivity of the subsurface layers.

From both surveys (GPR and ER) it is evident that the study area is made up three subsurface layers (lateritic topsoil, weathered layer and basement) as evident from their radargram reflection patterns and resistivity variations. 


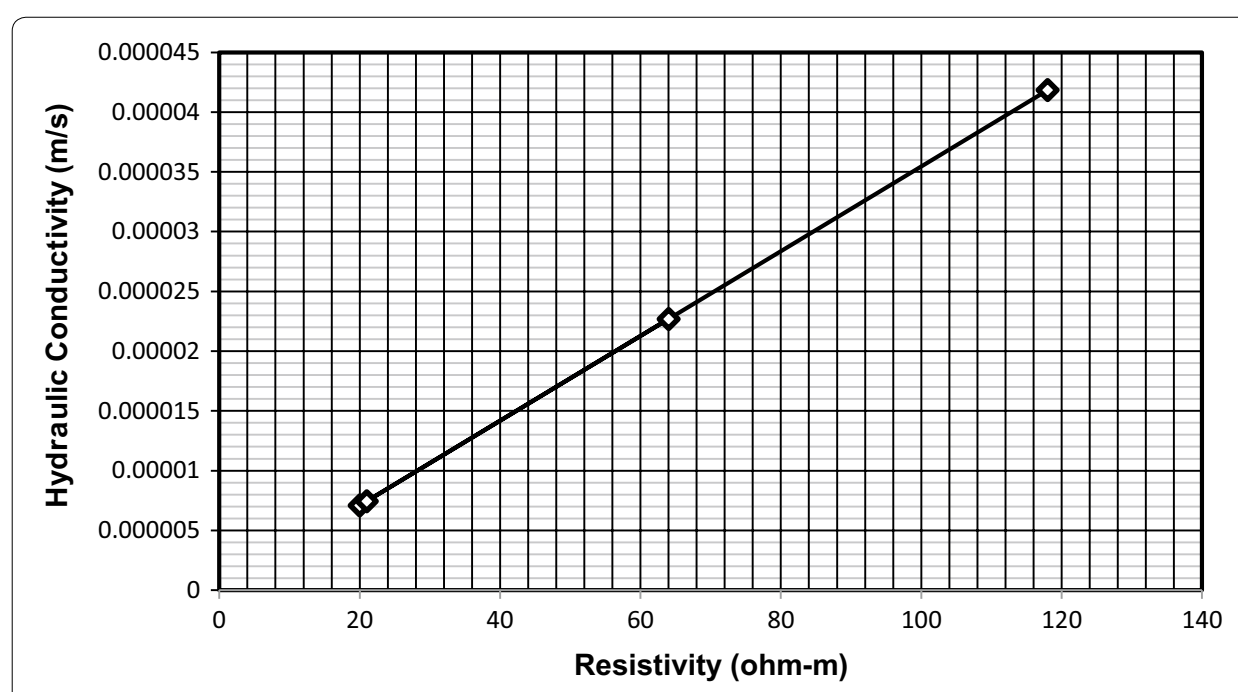

Hydraulic Conductivity of Weathered layer along Traverse 3

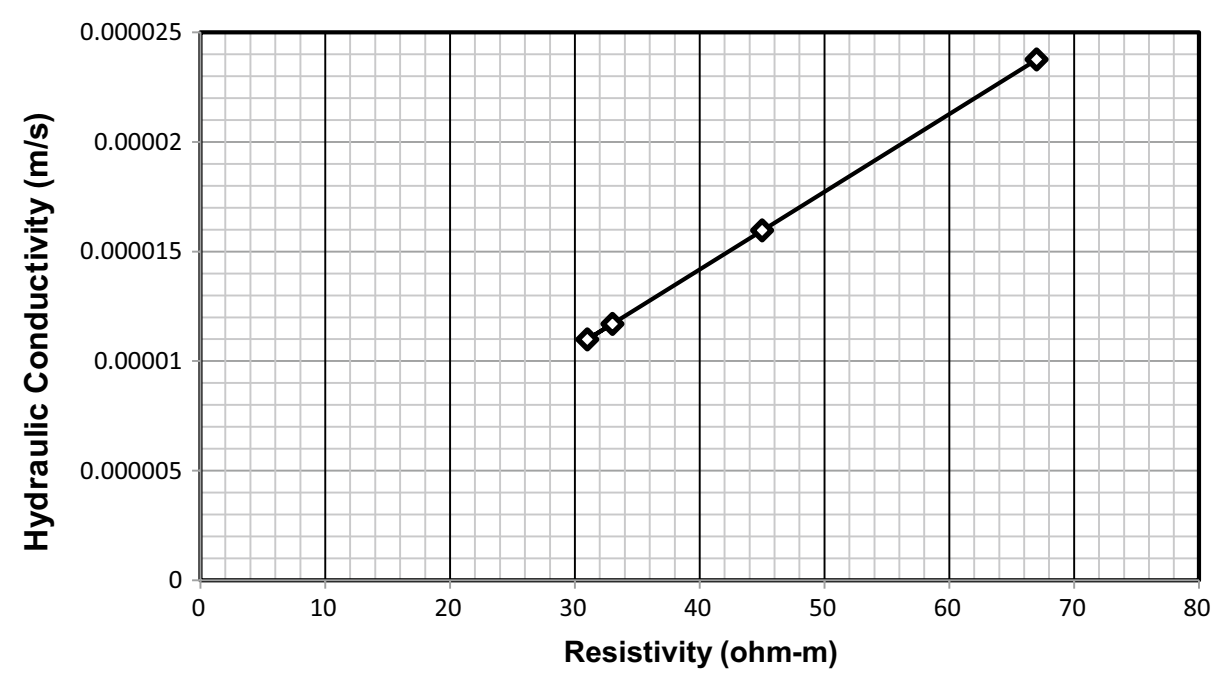

Hydraulic Conductivity of Weathered layer along Traverse 5

Fig. 16 Hydraulic conductivity of weathered layer along traverse 3 and 5

It is also evident from both surveys (GPR and ER) that the study area is made up of two distinct traverse set. One of which is made up generally of low hydraulic conductivity while the other is made up of high hydraulic conductivity. This is evident from the near smooth reflection pattern (weathered layer) and anomalous low resistivity values shown (Figs. 5, 6) whereas the other traverse set (Figs. 7, 8) displays subsurface layers with low 


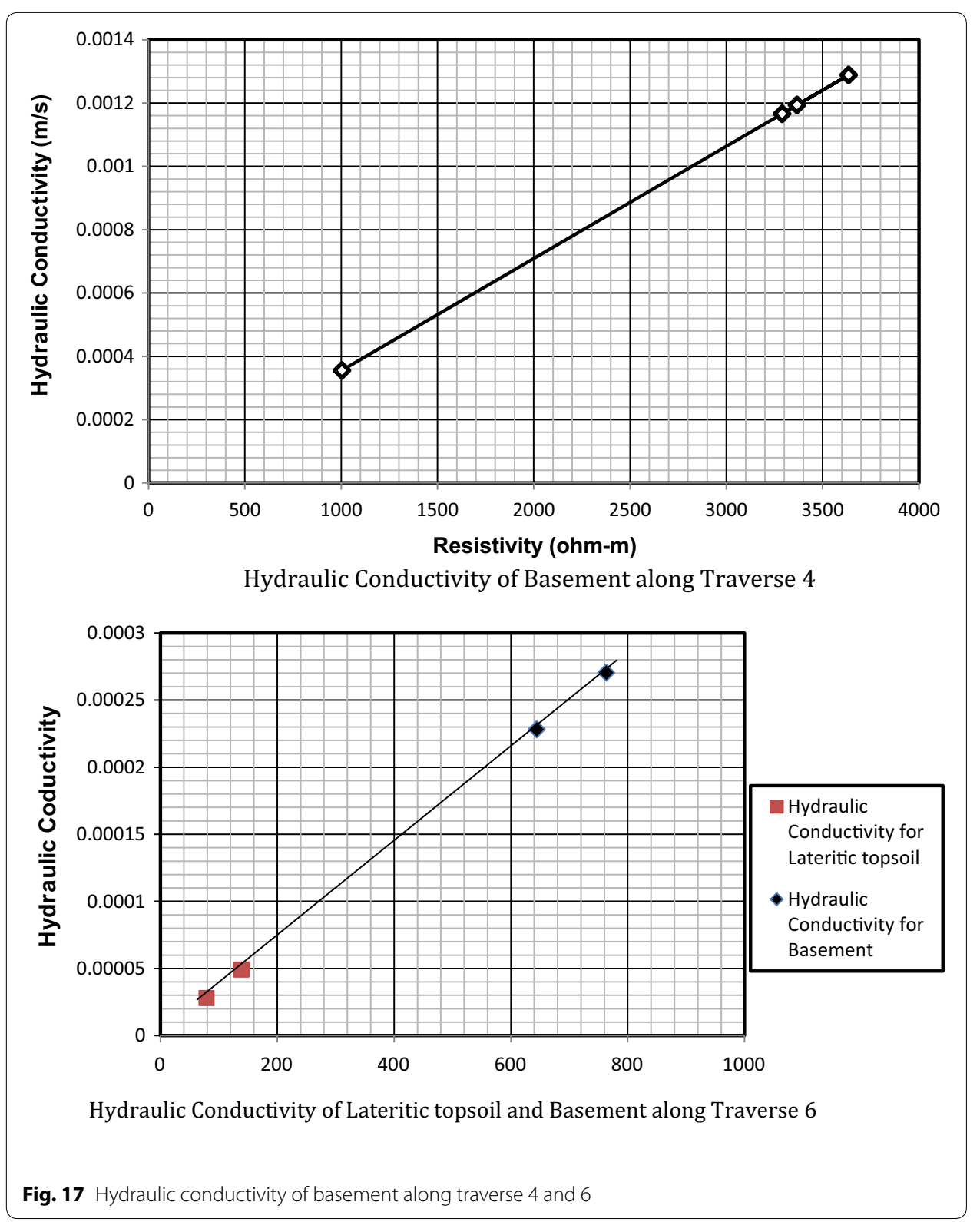

hydraulic conductivity evident by planar reflections/moderate resistivity values (lateritic topsoil) and chaotic reflections/high resistivity values (basement).

Both surveys (GPR and ER) reflect that certain traverses (1, 2, 3 and 5) at depths of about $5 \mathrm{~m}$ reflect high hydraulic conductivity values while others (traverses 4, 6, 7 and 8 ) reflect moderate to low hydraulic conductivity values. The traverses with high hydraulic conductivities correspond to traverses with low resistivities (with pores, cracks being water-filled) which makes them liable to groundwater seepage events. The traverses with 


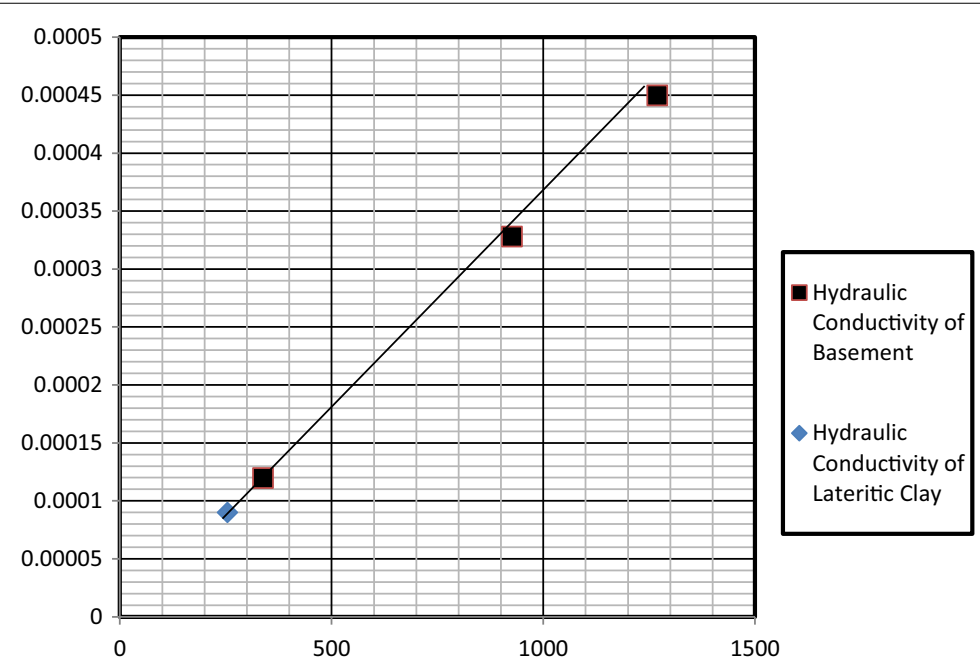

Hydraulic Conductivity of lateritic topsoil and Basement along Traverse 7

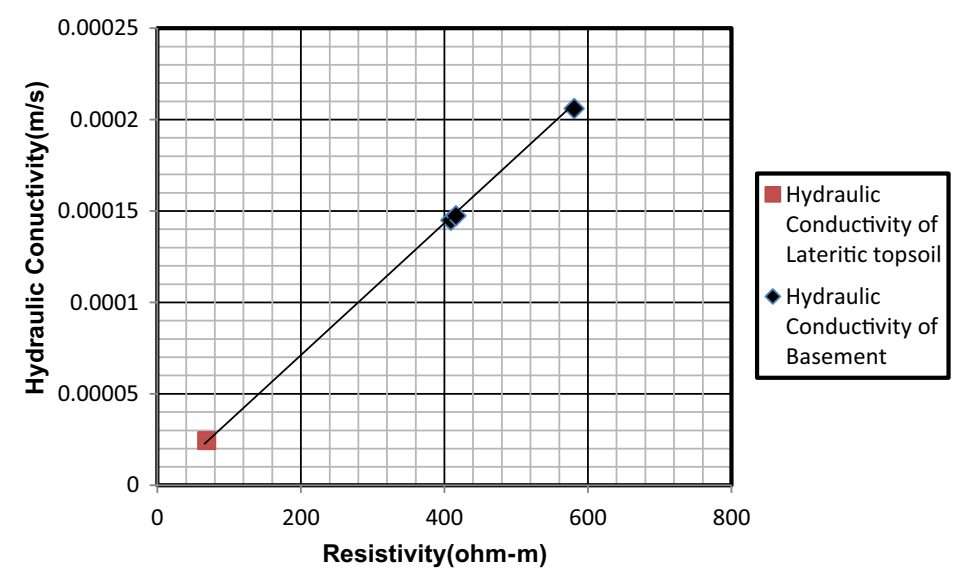

Hydraulic Conductivity of Lateritic topsoil and Basement along Traverse 8

Fig. 18 Hydraulic conductivity of basement along traverse 7 and 8

moderate and low hydraulic conductivities correspond to traverses with high resistivities and less liable to groundwater seepages.

Based on the various correlation instances pointed out, it could be suggested that the radargram (displaced by the GPR survey) and the geo-electrical sections (displayed by the ER surveys) give a fairly good correlation. As such both surveys (GPR and ER) give a fairly good correlation of results (Fig. 23). 


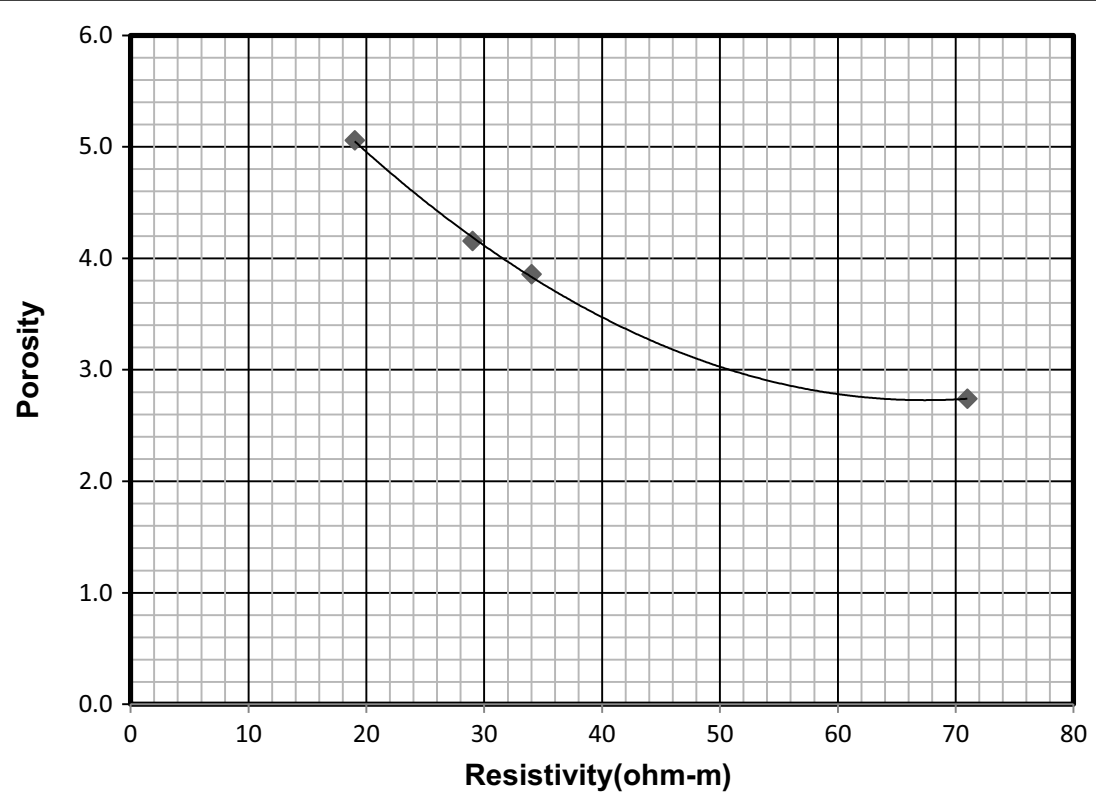

Porosity of Weathered layer along Traverse 1

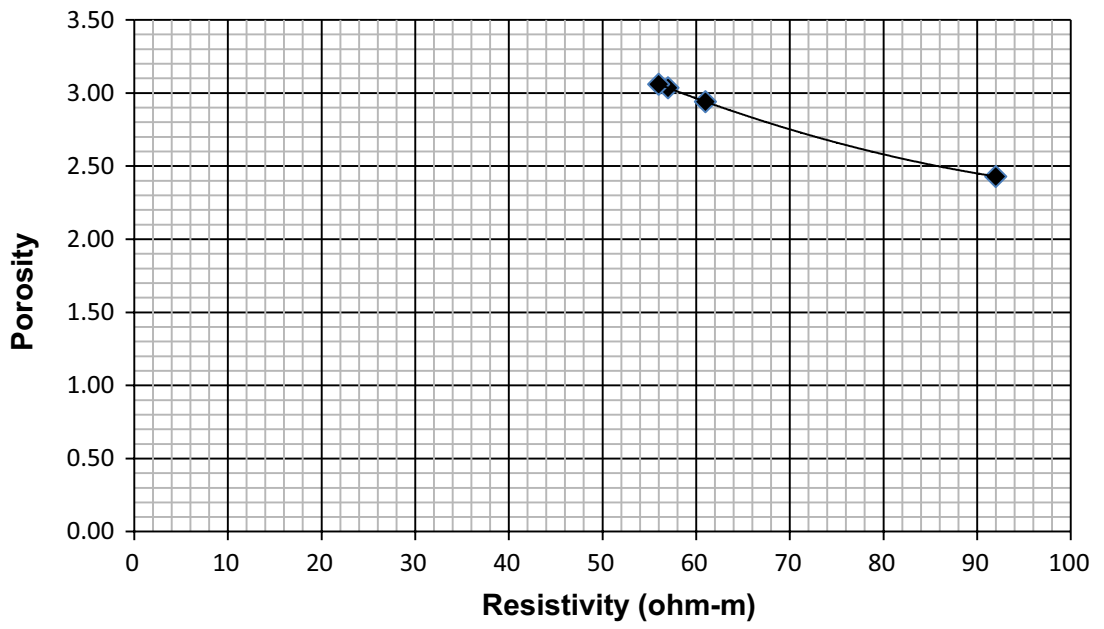

Porosity of Weathered layer along Traverse 2

Fig. 19 Porosity of weathered layer along traverse 1 and 2

\section{Conclusions and recommendations}

Integrated GPR and electrical resistivity data have been successfully used to relatively determine (varied reflection patterns) and quantify the hydraulic conductivities (K) of subsoil (lateritic topsoil and the weathered layer) found in the tropical region 


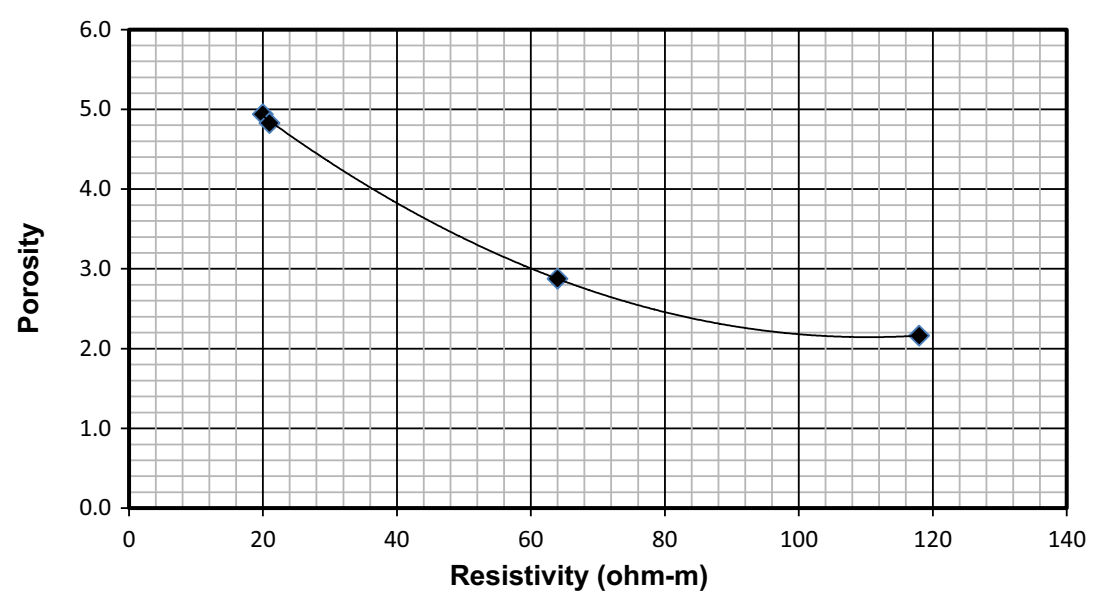

Porosity of Weathered layer along Traverse 3

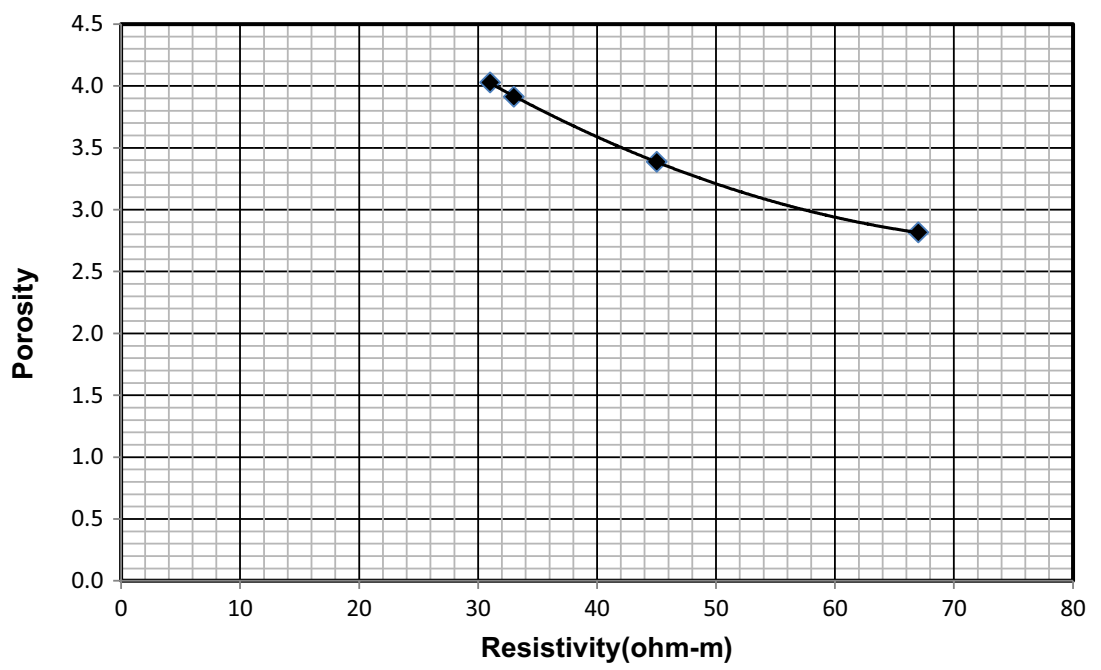

Porosity of Weathered layer along Traverse 5

Fig. 20 Porosity of weathered layer along traverse 3 and 5

of southwestern Nigeria. The integrated data showed that the weathered layer with smoother reflections and $\mathrm{K}$ values of $2.0 \times 10^{-5}-6.7 \times 10^{-6} \mathrm{~m} / \mathrm{s}$ is more liable to groundwater seepage as compared to the lateritic topsoil (semi-planar reflection and 


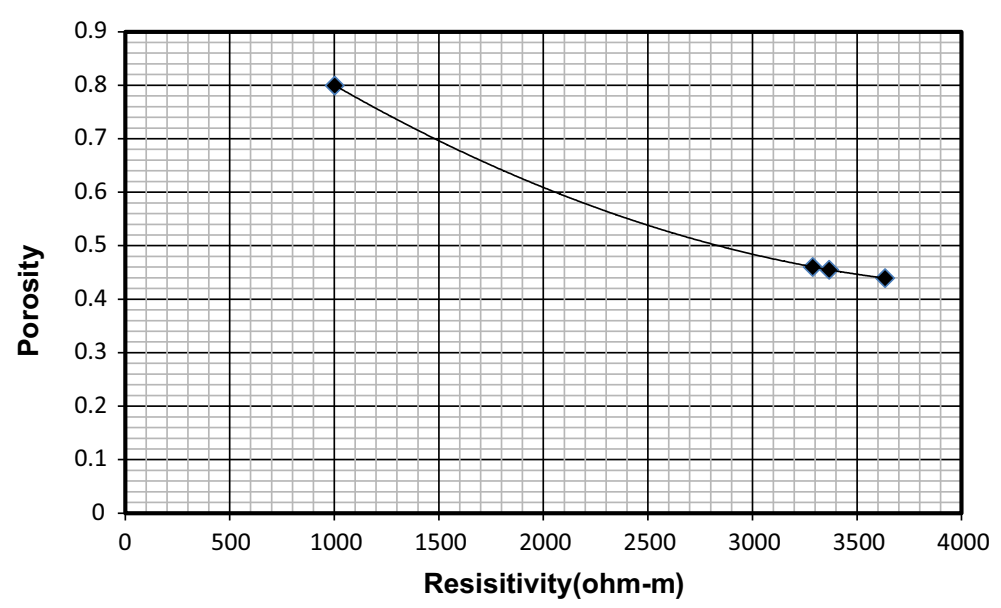

Porosity of Basement along Traverse 4

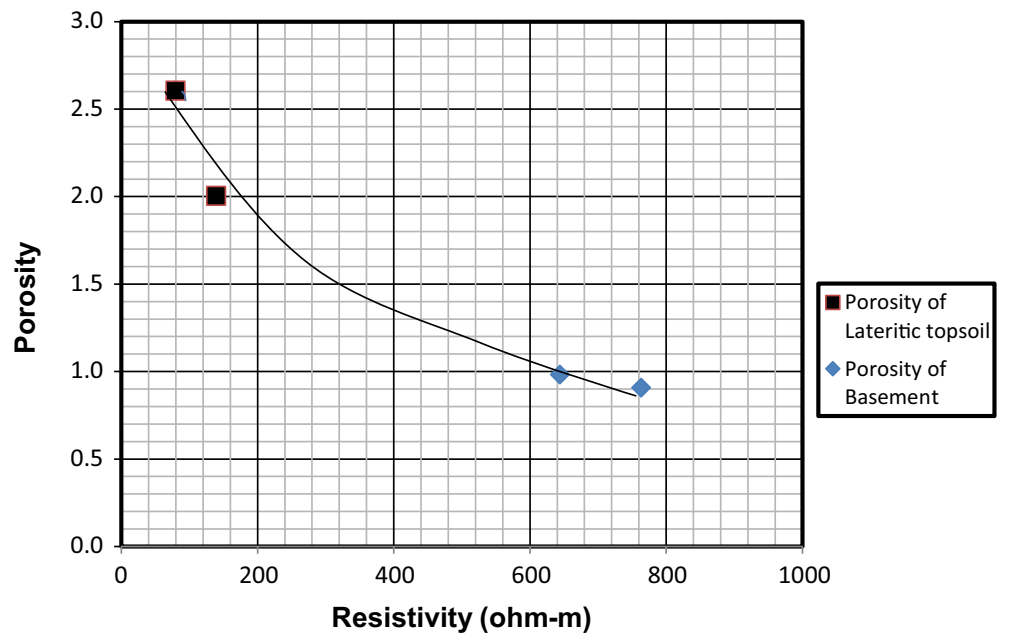

Porosity of Lateritic topsoil and Basement along Traverse 6

Fig. 21 Porosity of basement along traverse 4 and 6

$\mathrm{K}$ values of $2.4 \times 10^{-5}-9.0 \times 10^{-5} \mathrm{~m} / \mathrm{s}$ ) and the basement (chaotic reflections and $\mathrm{K}$ values of $1.6 \times 10^{-5}-9.3 \times 10^{-5} \mathrm{~m} / \mathrm{s}$ ). This been based on the variation in hydraulic conductivity values of the different subsurface layers (lateritic topsoil, weathered layer and the basement). Based on the $\mathrm{K}$ values houses situated along traverses 1, 2, 3 and 5 


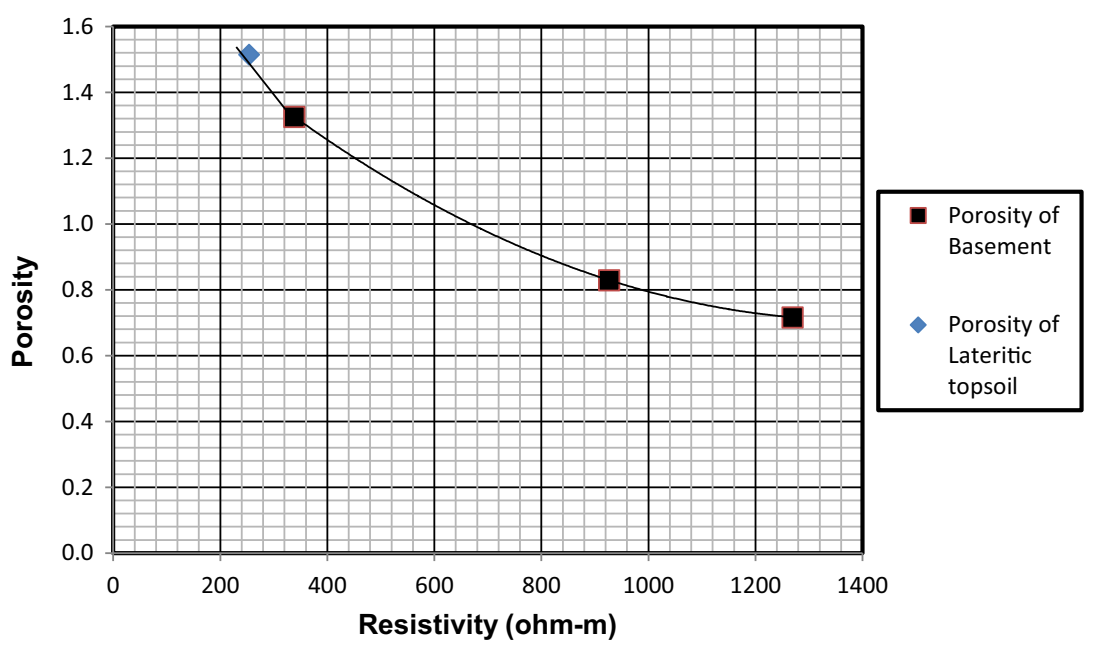

Porosity of Lateritic topsoil and Basement along Traverse 7

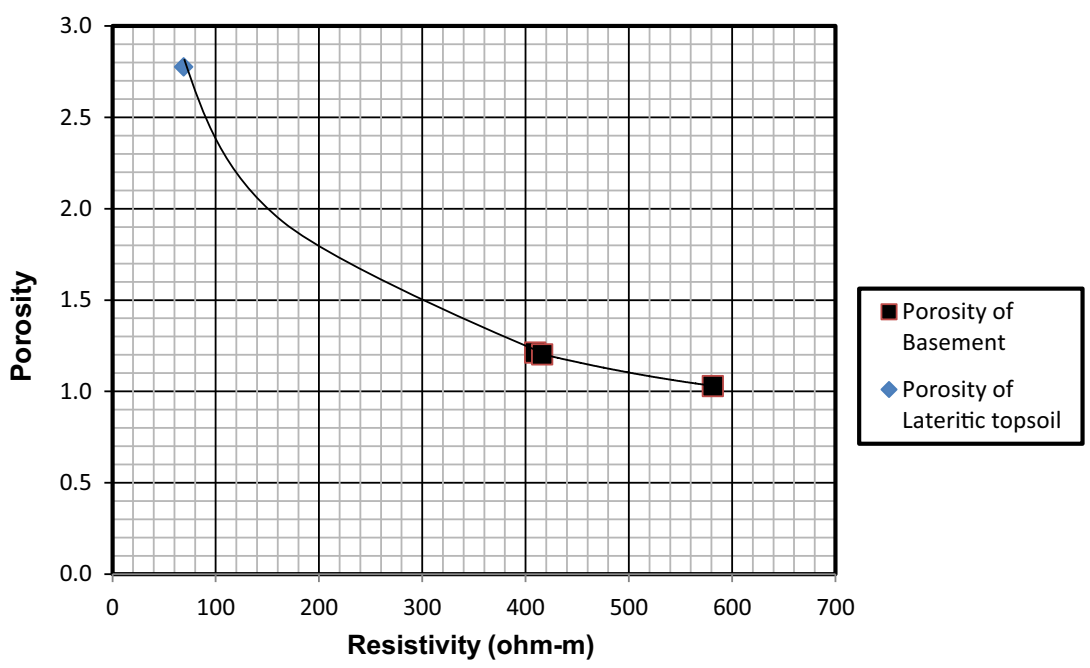

Porosity of Lateritic topsoil and Basement along Traverse 8

Fig. 22 Porosity of basement along traverse 7 and 8

are mostly prone to groundwater seepage than houses along traverses 4, 6, 7 and 8 . For houses along traverse 1, 2, 3 and 5; the adaptation of a dewatering system (construction of deep drainages) would be essential to direct away the flow of groundwater. Also deep trenches could be dug around foundations and then gravel packed to inhibit the effect of 


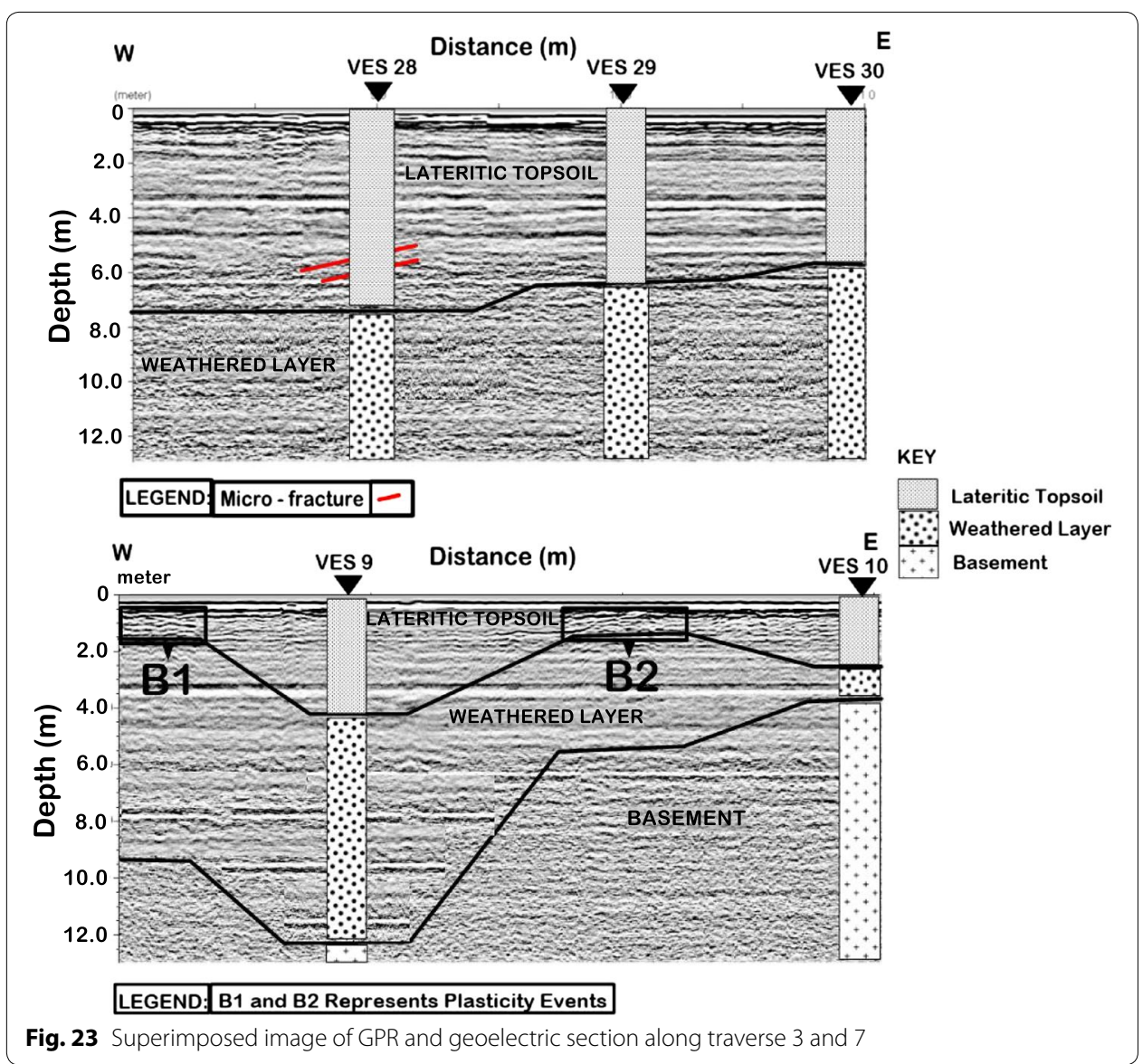

groundwater seepage. Based on the results obtained from hydraulic Vs. resistivity plots and the resistivity Vs. Porosity plots It could be suggested that the high values of the porosity, hydraulic conductivity observed probably enhanced the groundwater seepage experienced perennially in the area been investigated.

Received: 24 September 2015 Accepted: 23 February 2016

Published online: 19 April 2016

\section{References}

1. Adepelumi AA, Solanke AA, Sanusi OB, Shallangwa AM (2006) Model tank electrical resistively characterization of LNAPL migration in a clayey-sand formation. Environ Geol 50:1221-1233

2. Akinniranye OA (1985) Structural analysis of the basement complex of the Obafemi Awolowo University campus. Unpublished B.Sc. Thesis Obafemi Awolowo University, Ile-Ife, Nigeria

3. Antonio C (2006) Permeability-porosity relationship: a re-examination of the Kozeny-Carman equation based on a fractal pore-space geometry assumption. Geophys Res Lett 33(2). AGU Publications

4. Archie GE (1942) The electrical resistivity log as an aid in determining some reservoir characteristics. Petrol Transact Am Inst Mineralog Metallurg Eng 146:54-62

5. Archie GE (1950) Introduction to petrophyshics of reservoir rocks. AAPG Bulletin 34:943-961

6. Bakker MAJ, Maljers D, Weerts HJT (2007) Groundpenetrating radar profiing on embanked flodplains. Neth J Geosci 86(1):55-61

7. Conyers LB, Goodman D (1997) Ground Penetrating Radar for Archaeology. Walnut Creek, California

8. Fajobi AB, Falade FA, Adepelumi AA, Akindulureni JO (2015) Evaluation of hydraulic conductivity of lateritic soils using integrated approach: southwestern Nigeria case study. Int J Adv Geosci 3(1):1-7 
9. Johansson S, Dahlin T (1996) Seepage monitoring in an earth embankment dam by repeated resistivity measurements. Eur J Environ Eng Geophys 1(3):229-247

10. Knight RJ (1997) The role of ground penetrating radar and geostatistics in reservoir description. The leading edge 1617,1622, Nov

11. Lima OAL, Niwas S (2000) Estimation of hydraulic parameters of Shaly sandstone aquifers from geoelectrical measurements. J Hydrol 235:12-26

12. Matsui T, Kamiide S, Park S (1977) An applicability of resistivity-based high density prospecting to ground survey of mountain tunnel. Tsuchi-to-kiso 45:20-22

13. Møller I, Jørgensen F (2006) Combined GPR and DC Resistivity imaging in hydrogeological mapping. In proceedings of 11 th international conference on ground penetrating radar, June 19-22, 2006, Columbus Ohio. p 5

14. MuCurry P (1976) The geology of the precambrian to lower paleozoic rocks of Northern Nigeria. In: Kogbe CA (ed) Geology of lle-lfe, pp 15-39

15. Odeyemi IB (1976) Preliminary Report on the field relationship of basement complex rocks around lgarra, MidWestern State, Nigeria. In: Kogbe CA (ed) Geology of Nigeria, University of Ife

16. Ogata N, Ohsawa H, Nakano K, Yanagizawa K, Nishigaki M (1992) Relationship among lithology, permeability and resistivity and their application to modelling of hydrogeology. J Japan Soc Eng Geology 32:51-61. doi:10.5110/ jjseg.32.321

17. Olarewaju VA (1988) Petrology and Geochemistry of the Charnockitic and Associated Granitic Rocks of Ado-EkitiAkure area, Southwest Nigeria. In: Oluyide PO, Mbonu WC, Ogezi AE, Egbuniwe IG, Ajibade AC, Umeji AC (eds) Precambrian Geology of Nigeria, Geological Survey of Nigeria, pp 129-143

18. Olorunfemi MO, Olarewaju VO, Ajayi MA (1986) Geophysical investigation of a fault zone a case history from lle-lfe, South western Nigeria. Geophysical Prospecting, pp 1277-1284

19. Olorunfemi MO, Okhue ET (1992) Hydrogeologic and Geologic Significance of a Geoelectric Survey at Ile-Ife, Nigeria. Nigeria J Min Geol 28(2):221-229

20. Oyawoye MO (1964) The geology of the Nigeria basement complex. J Nigeria Min Geol Metall Soc 1:87-482

21. Rahaman MA (1976) Review of the basement geology of South-Western Nigeria. In: Kogbe CA (ed) Geology of Nigeria, Elizabethan Publishing Company, Nigeria, pp 41-58

22. Rahaman MA (1988) Recent advances in the study of basement complex of Nigeria. In: Oluyide PO (ed), Precambian geology of Nigeria, Geological survey of Nigeria, pp 11-43

23. Reynolds JM (1998) An introduction to applied and environmental geophysics. Wiley, New York

24. Sudo H, Tanaka T, Kobayashi T, Kondo T, Miyamoto M, Amagai M (2004) Permeability imaging in granitic rocks based on surface re-sistivity profiling. Explor Geophys 35:56-61. doi:10.1071/EG04056

25. Telford WM, Sheriff RE, Geldert LP (1990) Resistivity methods. In: Applied geophysics. Cambridge University Press, Cambridge, pp 523-524

26. Vander Velpen BPA (2004) WIN RESIST ${ }^{\mathrm{TM}}$. Electrical resistivity inversion program

27. Van Overmeeren RA (1994) Georadar for hydrogeologist. First Break 12:402-417

28. Welsh LA, Allen DM (2014) Hydraulic conductivity characteristics in mountains and implications for conceptualizing bedrock groundwater flow. Hydrogeology J; 2014. http://www.researchgate.net/journal/1431-2174_Hydrogeology_Journal 1007/s10040-014-1121-5. Accessed 10 Mar 2014

\section{Submit your manuscript to a SpringerOpen ${ }^{\circ}$ journal and benefit from:}

- Convenient online submission

- Rigorous peer review

- Immediate publication on acceptance

- Open access: articles freely available online

- High visibility within the field

- Retaining the copyright to your article

Submit your next manuscript at $\mathbf{s p r i n g e r o p e n . c o m ~}$ 